\title{
Income, Wealth, and Socialization in Argentina: Provocative Responses from Individuals
}

\author{
Daniel Lederman ${ }^{1}$ \\ Office of the Chief Economist, Latin America and the Caribbean Region, World Bank
}

April 2002

\begin{abstract}
$\underline{\text { Abstract }}$
This study has two objectives: (1) to establish a baseline measurement of "social capital" in Argentina; and (2) to identify its empirical determinants. The survey questionnaire designed for this study provides individual-level data about the population's participation in social organizations and its willingness to trust members of their community. Probit models are estimated to explain the individual's decision to participate and to trust strangers, where individual-household and community characteristics are used as explanatory variables. Potential simultaneity and endogeneity problems afflicting the empirical models are examined. The main determinants of the probability of participation in Argentina are age, age squared, household income (and perhaps income squared), rural communities (perhaps due to lower probabilities of migration among rural residents, since most migrants live in urban centers), perhaps community or provincial unemployment rates, and the individual's trust itself. In contrast, the main determinants of trust are age and age squared, but with the opposite signs to those exhibited by probability of participation, household wealth (but not its squared term nor household income), participation itself (as demonstrated by the SUR Probit results concerning the cross-correlation between the two social capital models), and especially the community or provincial unemployment rates and income inequality. It is also noteworthy that the common question on trust used in the U.S. General Social Survey and in the World Values Survey yields results where communities with higher "trust" rates actually have lower social participation rates. Finally, participation in organizations with participatory leadership selection mechanisms are more likely to produce interpersonal trust than other forms of participation.
\end{abstract}

JEL Classification: N3, O1, Z0.

\footnotetext{
${ }^{1}$ The opinions expressed in this paper do not represent the views of the World Bank. The team at Sofres-Ibope, Argentina, led by Enrique Zuleta, did a wonderful job with the implementation of the survey, and I thank them for their contributions to the design of the survey. Irene Novacovsky and Sandra Cessilini also provided useful guidance for the design and implementation of the survey in Argentina. Ana Maria Menendez provided research assistance in the initial stages. Kathy Bain, Robert Cull, Wendy Cunningham, Norman Hicks, Guillermo Perry, Norbert Schady, Claudia Sepulveda, and Maurice Schiff provided useful comments. All errors and omissions are my responsibility.
} 


\section{Introduction}

The number of articles and books on social capital has exploded in recent years. Robert Putnam's seminal work on social participation in the United States was finally published in 2000, but this work and his now famous work on Italian civic engagement are cited frequently (see Putnam 2000 and 1993). Coleman's (1990, chapter 12) definition of social capital is now a staple for rational choice social scientists. Economists have jumped on the bandwagon by studying the effects of "social capital" on various economic and social phenomena, including economic growth across countries (Knack and Keefer 1997; Zak and Knack 1998), village incomes in an African country (Narayan and Pritchet 1999), violent crime rates across countries (Lederman et al. 2001), and financial development within Italy (Guiso et al. 2000). ${ }^{2}$ Most studies use measures of "interpersonal trust" and "participation in social organizations" as proxies for "social capital." Instead of looking at the effects of social capital on economic and social outcomes, this study has two different objectives. One objective is to establish a baseline measurement of the level and geographic distribution of social capital in Argentina. The hope is that this measurement exercise will be replicated in a few years to monitor progress in the accumulation of social capital. The questionnaire designed for this study was applied to a national and regionally (in six geographic regions) representative sample of Arge ntine households. The sample was also representative of rural and urban communities. The number of responding households totaled 2235. The survey was implemented during May-June 2000.

A second objective follows a recent trend in the economics literature. This study attempts to clarify conceptually the meaning of "social capital" based on economic concepts and to

\footnotetext{
${ }^{2}$ Although most analysts find benign effects from social capital, there are a few skeptical views. Some argue that social capital is not a substitute for good governance by the state (Bowles 1999) and that not all forms of social
} 
explore its possible empirical determinants at the level of the individual. Knack and Keefer (1997) contributed to this line of inquiry by estimating correlations between aggregate (national) measures of social capital and various institutional and economic variables. Political scientists have also contributed to this line of research using individual-level data. Brehm and Rahn (1997) demonstrated, using individual-level data from the U.S., that confidence in public institutions, civic engagement and interpersonal trust are interrelated. More recent contributions to the economics literature on the determinants of social capital in the U.S. are DiPasquale and Glaeser (1998), Glaeser et al. (1999), and Alesina and La Ferrara (2000 and 1999). There are very few studies of the determinants of social capital in developing countries. ${ }^{3}$

Studies that explain individuals' decisions to trust other community me mbers and to participate in social organizations are interesting not only for academics but also for policymakers. Such studies contribute to policy discussions by contributing to our understanding of the accumulation of social capital: By understanding the determinants of social capital we might be able to design economic and social policies that promote socially benign social capital.

The main determinants of the probability of participation in Argentina are age, age squared, household income (and perhaps income squared), rural communities (perhaps due to lower probabilities of migration among rural residents, since most migrants live in urban centers), perhaps community or provincial unemployment rates, and the individual's trust itself. In contrast, the main determinants of trust are age and age squared, but with the opposite signs to those exhibited by probability of participation, household wealth (but not its squared term nor household income), participation itself (as demonstrated by the SUR Probit results concerning

capital, which benefit some groups at the expense of others, are necessarily benign (see Rubio 1997; Durlauf 1999; Portes and Landolt 2000; Lederman et al. 2001).

${ }^{3}$ Narayan and Pritchett (1999) studied the effect of social capital on incomes across villages in Tanzania. Schady (2000) studied the determinants of volunteerism in rural Peru. 
the cross-correlation between the two social capital models), and especially the community or provincial unemployment rates and income inequality. These results are consistent with the predictions of a simple economic model of the determinants of social capital, where participation is a flow variable, while trust is a stock variable.

The findings of this study have some important policy implications. First, it is important to promote social participation through economic policies that increase employment opportunities and income growth. Second, high levels of social participation at the community level augment individual trust, but social organizations should make special efforts to establish participatory leadership selection procedures. Finally, improving the share of income of the poorest, relative to the richest quintile, is likely to lead to increased levels of trust within Argentine society.

The rest of this study is organized as follows. Section II revisits concepts and measurement issues related to "social capital" by focusing on interpersonal "trust" and participation in social organizations. In addition, this section describes the survey questions used to measure these two types of social capital. Section III starts with a description of the levels and geographic distribution of aggregate measures of social capital across Argentine regions. The analysis then turns towards the structure of Argentine social capital by looking at aggregate participation rates in different types of social organizations. The types of organizations differ in terms of the level of internal participation by members, the types of leadership control structures, and other organizational features. Subsequently, the focus turns to a comparison of three different aggregate measures of "trust," which differ by the type of survey question used to construct each variable. Section IV presents a very simple economic model of social capital formation at the individual level, which serves as the guide for the specification of the econometric models. Section V discusses the estimation strategy, including two complications regarding the 
potentially simultaneous determination of the probability of participation and trust, as well as the potential endogeneity of some key explanatory variables. Section VI discusses the basic Probit results, while Section VII presents the results from SUR Probit regressions and TS-Probit regressions. Section VIII summarizes the findings and policy recommendations.

\section{Concepts and Measurement of Social Capital}

Social capital has been broadly defined as the set of rules, norms, obligations, reciprocity, and trust embedded in social relations, social structures, and society's institutional arrangements, which enable members to achieve their individual and community objectives (Coleman 1990; Narayan 1997). According to Portes and Landolt $(2000,532)$ "the definition of social capital as the ability to secure resources by virtue of membership in social networks or larger social structures represents the most widely accepted definition of the term today." Nevertheless, social capital is not a homogeneous concept but comprises various social elements that promote individual and collective action. It follows from this complexity that measuring social capital is problematic. Nevertheless, researchers have used --with varying degrees of success-- indicators of social capital based on people's participation in social organizations and the sense of trust among community members.

For economists, it is useful to draw analogies between physical and human capital and social capital. Coleman (1990, 304-305) put it in the following terms:

"Just as physical capital is created by making changes in materials so as to form tools that facilitate production, human capital is created by changing persons so as to give them skills and capabilities... Social capital, in turn, is created when the relations among persons 
change in ways that facilitate [collective] action... The function identified by the concept 'social capital' is the value of those aspects of social structure to actors, as resources that can be used... to realize their interests."

But this description of social capital does not establish the reasons why social interactions can produce useful resources for individuals. Coleman's argument is that social interactions, especially repeated interactions, produce obligations and expectations among individuals (Coleman 1990, 306). In the words of Brehm and Rahn (1997, 1001-1002), "The more that citizens participate in their communities, the more that they learn to trust others; the greater the trust citizens hold for others, the more likely they are to participate."

It is noteworthy that almost three decades ago, one of the creators of modern welfare economics, Kenneth Arrow, recognized the critical role of interpersonal trust:

"In the absence of trust... opportunities for mutually beneficial cooperation would have to be forgone... norms of social behavior... [may be] reactions of society to compensate for market failures (Arrow 1971, 22). ${ }^{.4}$

That is, from an economic viewpoint, social interactions can result in the establishment of norms -- or Coleman's obligations and expectations -- to satisfy the need to establish rules of behavior that are not automatically imposed by markets. Hence social capital can be seen as a social outcome that overcomes a market failure. While government is supposed to regulate the behavior of economic agents so that markets work better, repeated social interactions can also shape individual behavior so that markets work better. Likewise, government regulation of individual behavior can help promote social participation and consequently the formation of interpersonal trust. Figure 1 reproduces the schematic representation of the relationship between confidence in government, social participation and trust presented by Brehm and Rahn (1997). This rough 
model is useful to illustrate the complex relationships that may exist between these three concepts. Although it is difficult to control for the three community-level variables depicted in Figure 1, this study examines the determinants of social participation and trust at the individual level while controlling for the plausible correlation that might exits between these two variables. This issue is discussed in detail in the section about complications affecting the econometric estimation strategy. A later section of this paper presents a more detailed economic model of social capital formation by individuals, which shows how self-interest can lead individuals to participate in social organizations.

\section{The Level and Structure of Social Capital in Argentina}

\section{A. Survey questions on social capital}

Until recently, most research focused on aggregate outcomes of social capital, such as overall participation rates in social organizations (see Putnam 2000). In the United States, the workhorse for most empirical studies of social capital are the General Social Surveys (GSS), which ask individuals the following relevant questions: (1) "Generally speaking, would you say that most people can be trusted or that you can't be too careful in dealing with people?" (2) The GSS questionnaire includes questions regarding the respondents' membership in organizations such as political groups, religious organizations, unions, school associations, etc. Another survey that has been tested internationally is the World Values Surveys (WVS), sponsored by the University of Michigan in several countries around the globe, especially in industrialized

\footnotetext{
${ }^{4}$ This reference appears in Bowles (1999).
} 
countries and East and Central Europe. The relevant questions in the WVS are virtually identical to the GSS.

This approach has been questioned recently. Experimental evidence provided by Glaeser et al. (1999) shows that the question on interpersonal trust is not a good predictor of whether an individual will actually trust a stranger. The answers to this question seem to be more closely related to the respondent's perception of his or her own trustworthiness, thus producing a misidentification problem. Glaeser and his co-authors warn their readers about aggregation problems when using the individual-level responses to the general trust question. The concern is that the sum of positive responses on trustworthiness may not be a good aggregate approximation to the stock of social capital in a community, because trusting untrustworthy individuals may hurt naïve trustworthy individuals. The aggregate stock of social capital of a community should consider both positive and negative externalities that are difficult to ascertain and measure. At this time, there are no studies that provide methods for resolving this issue. Hence we opted to use different questions about interpersonal trust in an attempt to identify trust rather than trustworthiness. When aggregating the responses we simply added the positive responses and divided by the sample size to derive the trust rate, thus ignoring externalities. Some of the econometric results presented below seem to show that one of the questions used in the survey to some extent resolves the mis-identification problem.

The quantitative analysis to be presented below relies on three questions on trust. The first one (Trust I) is a hypothetical: "If you had to leave suddenly, whom could you trust to take care of delicate matters, such as your home, children or a dependent adult?" The respondent is presented with a set of options that includes family members. A respondent was considered to trust others if he or she answered that they could rely on someone other than a family member. 
The second (Trust II) question is similar to the GSS-WVS question: "The majority of people in this community are basically honest and you can trust them." Respondents were considered to trust others if they were in agreement or strongly agreed with the statement. The third question (Trust III) is similar the second one in its general phrasing, but actually asked about distrust: "Today you can't trust anybody." Those who did not agree with this statement were considered to trust others. Note that the latter two questions are more likely to suffer from the misidentification problem highlighted by Glaeser et al. (1999) due to the general and ambiguous phrasing of the statements.

Regarding the traditional questions on social participation, the main weakness of the GSSWVS approach is that the questionnaire does not request information about the internal organization of the groups in which the respondent participates. Therefore, it is impossible to investigate how the internal organization and membership composition of social organizations affects the production of interpersonal trust.

The Argentine survey improved on the GSS-WVS approach by including a series of detailed questions about the internal organization of the groups to which the respondent belongs. This is an improvement because individuals' decision to participate can be linked to the potential benefits (pecuniary or other) that can be derived from it. Control over management decisions, including fund management and leadership selection, may augment the capacity of individuals to derive social and economic benefits from their participation. Moreover, the composition of the membership of a group may affect the extent to which it has positive externalities on the rest of the community, as was argued by Durlauf (1999), Portes and Landolt (2000), Lederman et al. (2001), and several others. For this study, respondents were asked to identify the social 
organizations to which they belonged, and later were asked several questions about the internal organization of the group.

The questions about the internal organization of the groups covered the following issues: (1) Respondents were asked to characterize the process by which the organization or group makes decisions about fund management. If the respondent answered that "members debate and then decide" or if the respondent answered that "all members participate in the decision" then the organization was identified as having a "participatory fund management" decision process. (2) The process by which group leaders are selected was identified according to the following criteria: If the leadership selection process was by membership voting, volunteerism, spontaneous emergence of leaders, or simply without any leaders, then the respondent was identified as belonging to an organization with a "participatory leadership selection" process. (3) Respondents were also asked a set of questions about decision-making in general, not just in the management of funds. The same criteria used in (1) above were used to characterize organizations with "participatory decision-making."

(4) The homogeneity of the membership of the group was identified through a series of questions that asked the respondent whether the membership is composed of people belonging to the same family, religion, gender, political beliefs, occupation, age group, education level, income level, province, nationality, and people having the same problems. If a respondent answered in the affirmative on at least 3 or 4 out of these 11 questions (hence two indicators were created), then the individual was characterized as participating in an organization with a "homogenous membership." 
The following sub-sections show the participation rates by types of organization and trust rates. They also describe the geographic distribution of these rates across six Argentine geographic regions.

\section{B. The structure of social participation by organizational types}

Table 1 shows Argentina's participation rates by organizational types. The total participation rate is $19.7 \%$. A small number of them said that they participate in at least two $(2.2 \%)$ and an even smaller portion $(0.2 \%)$ said that they participate in at least three.

International studies use "membership density" as a measure of social capital, which is calculated as the average number of groups cited per respondent in each country. The data collected for this study implies a membership density of 0.21 . This number is well below the corresponding average membership density in Argentina for 1981 and 1990 as estimated by the WVS, which was 0.41. In a sample of 37 developing and developed countries with WVS data, Argentina's membership density was the lowest. The fact that the number estimated with this new survey instrument is lower should be taken with a grain of salt due to differences in survey design. ${ }^{5} \mathrm{~A}$ recent study by FLACSO (1997) estimated Argentina's participation rate at 20\%. Thus our current estimate seems reasonable. One point is clear: we have no evidence showing that Argentina currently is a country with a high level of social capital, and this new data on social participation is not encouraging.

\footnotetext{
${ }^{5}$ In the GSS and WVS, the question on membership is: "Now we would like to know something about the groups or organizations to which individuals belong. Here is a list of various organizations. Could you tell me whether or not you are a member of each type?" In contrast, the Argentina survey asked the respondent to list the groups to which he/she belongs and then was asked to use a list of 30 types of organizations to describe each one. It is likely that providing a list of organizations before asking about actual participation would have increased the reported number of groups in which the respondent participates.
} 
The rest of the analysis focuses on the primary organization identified by the respondents. The other participation rates shown in table 1 are subsets of the total, but they are overlapping subsets. The participation rate in homogenous organizations is 13.2 or $9.6 \%$, depending on the number of criteria used to identify homogenous organizations. Argentina's participation rates in the other organizational types reach similar levels, around $13 \%$, except for the case of participation in social organizations with participatory fund management, which has the lowest participation rate at less than $8 \%$.

Table 2 shows the corresponding participation rates across six geographic regions in Argentina. It is interesting to note that the Metropolitan region, composed of the Capital and surrounding settlements, has, by far, the lowest rates of participation. The highest overall rate of participation is in the Southern region, where over $26 \%$ of respondents participate. More remarkable is the fact that participation rates in organizations with participatory decisionmaking, including fund management, are quite high in this region. The rest of the regions have overall participation rates between 19 and $23 \%$. There is an interesting pattern related to participation in organizations with homogenous membership: the ranking of the regions depends on the number of criteria used to identify an organization with a homogenous membership. For example, the Metropolitan region has the lowest rate of participation in this type of organization when we use 3 criteria, but it is not the lowest with 4 criteria. The Northeast has the lowest participation rate when using 4. Another example is the Northwest region, which has the second highest participation rate in homogenous organizations when using 3 criteria, but falls to third place when using 4. These differences across regions beg the question of what social and economic characteristics (if any) may be related to cross-regional differences in participation. Also, as will be discussed later, regional participation rates may impact individuals' interpersonal 
trust, and thus it is interesting to ask whether marginal differences in participation rates have significant marginal effects on individuals' interpersonal trust. Some of these questions will be addressed in the econometric analysis presented below.

\section{The structure of trust by survey question}

Table 3 shows Argentina's "trust rates," which differ by the survey question used to identify individuals with interpersonal trust. The percentage of respondents that answered in the affirmative to the first, hypothetical trust question (Trust I) was 33.1\%. The corresponding percentages derived from the more general trust questions (Trust II and III) are almost twice the first one, reaching 66.8 and $57.7 \%$, respectively. Hence the question used produces dramatically different results. As will be seen later, there are also significant differences in terms of the predictions about individual social participation produced by these three different indicators of community trust.

The regional trust rates show that the one derived from the hypothetical questions (Trust I) exhibits the lowest rates. The fourth region is the only exception, where the third type has a lower rate. According to Trust I, the highest rates of trust are found in the fourth region, followed by the sixth and second regions. Using Trust II, the highest rate is in the third region, followed by the first. The ranking of the regions is also different when using Trust III, which shows the fifth region in first place, followed by the third region. It is important to understand how these different "types" of trust affect social participation by individuals. Without this type of analysis, it is virtually impossible to make any sort of recommendation about how to measure interpersonal trust. Furthermore, in order to have an informed policy discussion about how trust 
can be enhanced in Argentina, we need to know not only what is the desirable trust question, but also what are the determinants of an individual's decision to trust others.

\section{An Economic Model of Social Capital Formation ${ }^{6}$}

Before proceeding with the empirical analysis of the determinants of social capital in Argentina, it is important to establish some testable hypotheses. In this section we present a simple model of an individual's decision to invest time in accumulating social capital by participating in social organizations, based on expected costs and benefits. This approach is consistent with the sociological (Coleman 1990; Portes and Landolt 2000) and the economic literature (DiPasquale and Glaeser 1999) that emphasize the definitions of social capital linking the ability of individuals to secure resources through their membership in social networks.

The decision to participate in social groups can be modeled as a dichotomous outcome. The individual decides whether or not to participate based on the expected net benefits:

(1) $\quad D=1$ if $n b(D) \geq 0 ; D=0$ otherwise.

"nb" stands for the net benefit. D is the decision to participate in social organizations; it equals one whenever participation in a social organization produces positive net benefits. In turn, these net benefits can be disaggregated into utility effects, where some are positive and some are negative as follows:

\footnotetext{
${ }^{6}$ For alternative theoretical models of social capital formation see Glaeser et al. (2000) and Alesina and La Ferrara (1999).
} 


$$
n b(D)=U(\Delta S K(D)-w \bullet T(D)-\delta \bullet \Delta S K \bullet \overline{S K}) \geq 0 .
$$

The first negative term on the right hand side of equation (2) represents the opportunity cost of participation $(w \bullet T(D))$. It is the product of the wage rate $(w)$ times the amount of time invested in participating, which is itself a function of the decision to participate $(T(D)){ }^{7}$ The opportunity cost of time could include losses related to lost leisure and other foregone activities such as family responsibilities.

The second negative term represents the loss of social capital that would be produced by its depreciation, which depends on the expected probability of migration. This term is necessary because social capital is presumed to be specific to the community. After an individual moves to another place, his/her social capital stock depreciates by a given portion of the overall community stock of social capital $(\overline{S K})$. For example, friendships and business connections in one community might be less useful in another (as in Schiff 1999). Following Glaeser et al. (2000), the expected depreciation rate $(\delta)$ reflects the probability of moving to another community:

$$
\text { (3) } \delta=\theta \bullet \lambda \text {, }
$$

where $\theta$ is the probability of moving to a different community and $\lambda$ is the rate of depreciation of social capital resulting from the move. The last term in (2) also includes an interaction between the net change in the individual's social capital and the community's stock of social

\footnotetext{
${ }^{7}$ Please note that parentheses represent functional dependence, while interactions are represented by " $\bullet "$. The only exception to this notation is the parenthesis in equation (3), which denotes a subtraction between the terms inside the parenthesis.
} 
capital, because the benefits (and reduced benefits from migration) depend on the interaction of the individual with a given community. In the model, $\Delta S K$ could be interpreted as the change in the level of interpersonal trust, which depends on the decision to participate. Also, $\overline{S K}$ is the aggregate level of trust in the community. ${ }^{8}$

The first positive term on the right-hand side of equation (2) represents the increase in utility that would be brought about by the decision to participate, which produces a change in the stock of social capital $(\Delta S K)$ belonging to the representative individual. In turn, this utility function can be dis-aggregated into two components:

$$
U(\Delta S K(D))=U(w(\Delta S K(D) \bullet \overline{S K})+\Delta S K(D)) .
$$

The first component $(w(\Delta S K(D) \bullet \overline{S K}))$ is an expression linking the wage rate of the individual to his/her change in social capital times the community's social capital. In other words, it is assumed that increases in social capital brought about by increased social participation can produce increases in productivity. Collier (1998) proposed this type of productivity-enhancing effect. For the case of Tanzania, Narayan and Pritchett (1999) identify a variety of channels through which social capital might raise village incomes, including increased community effectiveness in monitoring the quality of public services, enhanced community cooperation, increased innovation diffusion, and other actions that lead to productivity increases. The second term $(\Delta S K(D))$ in equation (4) argues that an individual's utility can be directly and positively affected by his/her social capital. For example, individuals could gain utility by forming

\footnotetext{
${ }^{8}$ There is some ambiguity in the literature about whether participation is a flow or a stock variable -- see Glaeser et al. (2000). In this model, trust is treated as a stock and participation leads to a flow or change in interpersonal trust.
} 
friendships or any type of social connection that enhances their social status or wellbeing. Several authors, such as Robison and Siles (1997) and Schiff (1992), propose this type of direct utility-enhancing effect. It is impossible to ascertain the magnitude of this effect. By inserting equation (4) into equation (2) and rearranging terms so that the direct utility-enhancing effect appears to the right of the inequality, we get:

$$
D=1 \text { if } U(w(\Delta S K(D) \bullet \overline{S K})-w \bullet T(D)-\delta \bullet \Delta S K \bullet \overline{S K}) \geq-U(\Delta S K(D), D=0 \text { otherwise. }
$$

Since the very last term in equation (5) is unobservable, this model can be summarized as stating that an individual will participate in social organizations to accumulate social capital whenever the observable net benefits (those on the left side of inequality (5)) exceed an unobserved threshold.

From (5), we can derive testable hypotheses. First, the wage rate appears with both a positive and a negative influence on the index that determines the decision to participate. The wage itself depends on the decision to participate and it is endogenous. This should be taken into account when choosing the estimation strategy. Second, the prospects of migration (or geographic mobility) seem to reduce the likelihood that an individual will participate. Third, the productivity-enhancing effect depends on the interaction of the community's social capital with the individual's net increase in social capital. Factors such as the level of education, age of the individual and his/her profession may determine the magnitude of this effect. Moreover, education and age may simultaneously determine the threshold level of the index. Therefore, in

This reasoning is consistent with Collier (1998) and Coleman (1990) who see trust as the outcome from social interactions. 
the following empirical analysis we will test these hypotheses, while also controlling for other factors that may determine the individual's decision to participate.

\section{Empirical Determinants of Social Capital in Argentina}

\section{A. Explanatory variables}

Based on the theoretical model presented above, and the arguments coming from the political science literature cited earlier, the empirical analysis should aim to control for three potential causes of social participation and trust. Determinants of the individual's income should be considered, including age, level of education and (the natural logarithm of) current income of the household. Also, we can expect non- linear effects from age, education and income on the likelihood that an individual will participate in social organizations. This is due to the fact that the wage rate theoretically can have contradicting effects on social capital formation. Therefore, it is possible that for certain ranges of age, education and current income the ne gative effect will predominate over the positive effect. For example, Glaeser et al. (2000) show theoretically and empirically that age has non-linear effects on participation density across US jurisdictions, presumably because young and elderly individuals who are not at their peaks in terms of economic participation in the labor market tend to have low participation densities. The data summarized in figure 2 shows that there might be a non-linear relation between trust and household income. This hypothesis will be tested econometrically.

The employment status of the head of household may affect his/her decision to participate as well as the decision to participate by other members of the household. The reason is that 
participation may take away time from the job search and from additional work that other household members might be required to undertake in order to make-up for the family's loss of income. Alternatively, participating in groups where the individual can make professional contacts may enhance the job search. The analysis will control for the employment status of the household head.

Education may impact interpersonal trust and social participation through non-economic channels, because education "may help to create a climate of trust that is self-reinforcing" (Helliwell and Putnam 1999, 5). The probability of participation could also be affected by the experience of having been the victim of a crime. Also, it is likely that victimization may reduce individuals' willingness to trust strangers (Alesina and La Ferrara 2000). The data for these variables was collected by the survey.

An alternative concept related to income is household wealth. The difference is that income, as reported by the survey data, is actually an approximate indicator of current income flows, while household wealth should reflect the stock of wealth. The latter can be represented by the ownership of assets and consumer durables. We used the first principal component of a set of variables to construct an index of household wealth. The variables included homeownership, the number of rooms per capita in the dwelling, the number and types of automobiles owned by the household, plus the ownership of other consumer durables, including personal computers, refrigerators, etc. In theory, the wealth index should help explain "stock" indicators of social capital (perhaps trust), while the current income variable should help explain "flow" indicators of social capital (perhaps participation). The data summarized in figure 3 indicates that there could be a linear relation between trust and wealth. This hypothesis will be tested. 
As mentioned earlier, the individual's wage rate is likely to be endogenous to the decision to participate, and wealth itself may be determined by the stock of social capital held by the individual. This could also be true for the employment status of the individual. To control partially for this endogeneity, the Probit models to be presented below use the household's income per capita and wealth index as an explanatory variable for the individual's decision to participate and trust strangers. For employment, we also use the employment status of the head of household rather than status of the individual. However, since it is likely that income is correlated among members of the household, this approach might not fully control for endogeneity, and therefore some of the results presented below could have an upward bias in the estimated coefficients of the income and wealth variables.

Community characteristics that may affect the extent of the benefits of social participation should also be included as explanatory variables. For example, Zak and Knack (1998) find that income inequality (as well as ethnic diversity) reduces trust rates across countries, and Alesina and La Ferrara (1999) find that community income inequality (and other forms of hetergoneity) are associated with lower probabilities of participation by individuals. For the case of Argentina, which has been suffering from double-digit unemployment rates, which in turn might cause social tension, community- level unemployment rates might be associated with lower probabilities of social participation and trust at the level of the individual. To control for these two community characteristics (i.e., income inequality and unemployment), this study relies on data from Argentina's statistical agency (INDEC), which permits the calculation of measures of income inequality and unemployment across the twenty-two provinces.

To control for the probability of geographic migration, we include a household variable about homeownership that identifies individuals who live in homes owned by the household. The 
intuition is that homeownership ties individuals to their communities by raising the costs of migration. This variable works quite well with US data (DiPasquale and Glaeser 1998). A community-level variable that might be linked to the probability of migration in Argentina is an identifier of individuals who live in rural areas. The expected probability of migration is lower for rural households because most migrants reside in urban centers. These two variables (homeownership and the identifier of rural communities) were also collected by the survey. ${ }^{9}$

\section{B. Estimation strategy}

\section{Basic models}

The model indicates that a Probit model approach might be adequate. Following Alesina and La Ferrara (1999 and 2000), the estimation strategy can be represented as:

(7) $\operatorname{Pr}\left(D \neq 0 \mid X_{i c}, H_{c}\right)=\Phi\left(X_{i c} \beta+H_{C} \gamma\right)$,

where subscripts $\mathrm{i}$ and c stand for individuals and communities (regions or provinces in our case), respectively, and $\Phi$ is the standard cumulative normal with mean zero and variance 1 . X represents individual characteristics; $\mathrm{H}$ represents community variables. The latent, unobserved Probit index is a function of $\mathrm{X}$ and $\mathrm{H}$. Only the outcomes of the individual's decisions (D) to participate and his/her answer to the trust question are observed.

\footnotetext{
${ }^{9}$ Table A1 in the appendix contains the summary statistics of the explanatory variables for the whole sample of respondents, for those who are heads of households, and for those who are not heads of household. The distinction between these two groups is imp ortant for the econometric estimates that use characteristics of the household head as instruments for some explanatory variables that might be endogenous -- see sections V, VI, and VII.
} 
Section VI presents the econometric results from the Probit models. The presentation of the basic results is limited to the "marginal effects coefficients," which show the effect on the probability that an individual will participate (or trust non-family members) of a discrete change in a continuous variable or of having a particular characteristic. For continuous explanatory variables $X_{i c 1}$ and $H_{c 1}$, we present the following types of coefficients estimated at the means of $X_{i c 1}$ and $H_{c 1}$ :

$$
\frac{\partial \Phi}{\delta X_{i c 1}}=f\left(\overline{X_{i c}} \beta\right) \beta_{1} \text { and } \frac{\partial \Phi}{\delta H_{c 1}}=f\left(\overline{H_{c} \gamma}\right) \gamma_{1}
$$

where $\overline{X_{i c}}$ and $\overline{H_{c}}$ are the sample averages of the individual and community variables, respectively.

The standard errors of the estimated coefficients to be presented are Huber-White errors, which are adjus ted for heteroskedasticity of unknown form. We also allowed for independence of the error terms across settlements, but we allowed for dependence or clustering of the error terms within settlements. ${ }^{10}$ This correction of the standard errors of the estimated coefficients is necessary since settlements were surveyed on different days by different people, and thus the observations within settlements are likely to be closer to each other than they are to observations from other settlements.

The estimation strategy begins with the inclusion of individual and household characteristics together with regional dummy variables. This "basic" specification analyzes the impact of the $\mathrm{X}$ variables while controlling for unknown community effects. In turn, the regional

\footnotetext{
${ }^{10}$ The 36 settlements are listed at the bottom of tables 2 and 4 .
} 
dummy variables are replaced with continuous community variables. This specification explores specific variables that may drive the community effects.

Section VI, which discusses the basic regressions, also analyzes some simple correlations between individual participation and the three community- level indicators of trust. Likewise, after examining the basic determinants of individual trust (I), which seems to be the more reasonable measure of trust, section VI also looks at simple correlations between individual trust and participation in the various types of organizations as defined earlier (i.e., homogeneity of membership with two criteria, fund management, decision making, and leadership selection mechanisms).

\section{Complications: simultaneity and endogeneity problems}

Section VII attempts to address two estimation challenges. The first is related to the possibility that individual participation and trust are simultaneously determined. This can occur either because they cause each other as argued by Brehn and Rahn (1997), or because they have some common omitted determinants. Generally speaking, ignoring this potential correlation between participation and trust might reduce the efficiency of the estimates, or even produce biased estimates if these variables are correlated with other included explanatory variables. To examine the impact of controlling for this correlation, this study estimates a system of two equations (one for participation and another for trust), while allowing for their error terms to be

correlated. That is, seemingly unrelated (SUR) Probit regressions are estimated for this purpose. This approach has been used in other areas of applied economics, such as Hassan (1996), which examines how different planting choices affect each other in the cultivation of maize in Kenya. 
The second complication is the possibility that some of the explanatory variables in either the participation or the trust regressions are endogenous. In particular, given the common finding that social capital helps determine household incomes and wealth, we need to address the possibility that the Probit estimates might be inconsistent (or biased) due to reverse causality running from participation (trust) to household income (wealth). To control for the potential endogeneity of these variables, I employ Newey's (1987) two-stage maximum likelihood or Probit estimator designed to control for the endogeneity of continuous explanatory variables. This approach has been used in other areas of applied research by Ribar (1994) and Norton et al. (1998). Ribar used it to control for the endogeneity of continuous indicators of teenage fertility as a determinants of the dichotomous decision variable concerning high school completion. This author finds that the negative effect of fertility on high school completion are greatly exaggerated by endogeneity. Norton et al. use this technique to control for the endogeneity (caused by the selection of peers) of the average peer substance abuse as a determinant of the likelihood of substance abuse by adolescents, and find that peer selection did not produce any measurable endogeneity biases. To test directly for the endogeneity of these variables, I estimate Rivers and Vuong's (1988) simple endogeneity test, which examines the statistical significance of the residual of household income (wealth) from an income function that includes all the exogenous explanatory variables as determinants of income (wealth). The null hypothesis of this test is that the income (wealth) residual is not correlated with participation (trust). Therefore a p-value above $5 \%$ of this test indicates that income (wealth) is not endogenous.

To secure reliable instrumental variables for household income (wealth) I use the age, age squared, years of education, and years of education squared of the head of household. Thus the TS-Probit models were estimated with the sample of individuals who were not heads of 
household. The alternative specification, which would use the characteristics of the non-heads as instruments for household income (or wealth), was not used due to a rather large set of missing observations. $^{11}$

All econometric models are estimated with data for the respondents only for two reasons. First, the data for non-respondents is likely to be less reliable than the data for respondents. Second, the trust regressions can only be applied to respondent data, because the trust questions could not be answered by the respondent on behalf of other members of the household. The data used in the regressions was not weighted, because it is unclear what criteria were used by the surveyors to estimate the proper weights. The following sections discuss the econometric results.

\section{Determinants of Social Participation: Basic Regressions}

\section{A. Social participation}

Table 5 shows the basic Probit results for the determinants of the probability that an individual will participate in any social organization. In the second column, the first panel shows the estimated marginal effects coefficients for the age of the respondent, age squared, the natural logarithm of the household's income per capita, and the logarithm of income per capita squared. The squared terms of both variables were included to test for the existence of non- linear effects. The results show that both variables have significant non-linear effects. However, the direction of the non-linear effects of age and income are different. The probability of participation is rising

\footnotetext{
11 The survey asked respondents to describe the characteristics of all members of the household. The data required to construct the proper instruments are the average age and years of education of the household members excluded from the sample. I need to investigate further why it seems that household heads were less willing to provide information about the rest of household members.
} 
initially with age, but at a progressively lower rate, as shown by the negative and significant coefficient of the squared age variable. The probability of participation is initially declining with income but eventually rises. The estimated coefficients imply the following marginal effects of age and income on the probability of participation: ${ }^{12}$

$$
\begin{aligned}
& \frac{\partial \Phi}{\delta A g e_{i c}}=0.008-0.000 \cdot 2 \cdot \text { Age, and } \\
& \frac{\partial \Phi}{\delta \operatorname{Ln}(\text { income })_{i c}}=-0.114+0.012 \cdot 2 \cdot \operatorname{Ln}(\text { income })
\end{aligned}
$$

Figures 4 and 5 show the actual marginal coefficients for the whole sample, sorted by age and income, respectively. In the case of age, over $72 \%$ of the sample, have positive marginal coefficients; only individuals over 53 years of age have negative marginal coefficients. In the case of income, over $73 \%$ of respondents have positive marginal coefficients; only individuals living in households with less than a monthly income of $\$ 97$ per capita have negative marginal coefficients. Referring back to the theoretical model presented above, in economic terms these results indicate that for almost three quarters of the population, the marginal benefits (i.e., the sum of pecuniary and non-pecuniary benefits) exceed the marginal opportunity cost of social participation. For the poorest quarter, however, the marginal costs exceed the marginal benefits of participation.

Individuals who belong to households where the head is unemployed have a lower probability of participation. The gender variable is significant only in the first specification and disappears when the wealth index is introduced in the second specification. The only significant

\footnotetext{
12 The reported "0.000" estimate for age squared is small but positive (0.0000796). All reported coefficients are rounded up to the third decimal point. Note that the coefficient on the levels of age and income are no longer
} 
educational variable is the identifier of respondents who have received their university degree, but this result is only present in the second model. Some community variables in these models are significant. Residents of rural communities have a higher probability of participation than urban dwellers (by about 0.090 ), perhaps reflecting a lower probability of migration. Residents of region 1 have lower probabilities of participating than residents of region 6 , which is the control group in both models. In the following exercises we present additional results that investigate how different community (or regional) characteristics affect individual probabilities of participation.

In the third column of table 5, neither the level nor the squared of the wealth index are significant. These results are consistent with the view that participation is a "flow" rather than a "stock" indicator of social capital. The only variable that is not robust to the inclusion of the wealth variables is gender, which is no longer a significant determinant of participation.

Table 6 presents the Probit regressions that include continuous community variables. When the provincial unemployment rates and the relative income ratio of the poorest quintiles are included as explanatory variables, the results concerning the individual and household characteristics all remain unchanged. The dummy for rural communities also retains is positive and significant coefficient. The unemployment rate appears the expected and significant negative coefficient. A one-percentage increase in the provincial unemployment rate is associated with a 0.008 percent decrease in the probability of individual participation. The provincial income ratio is not a statistically significant determinant of the probability of participation.

To wrap-up the discussion on participation and as a precursor to the discussion of trust determinants, Table 7 shows the simple linear correlation coefficients between the six regional trust rates for the three "types" of trust (which differ by their survey question, as mentioned

\footnotetext{
"marginal" coefficients.
} 
above) and the individual probability of participation by the respondents. The model presented in this paper views trust as a stock variable, and higher stocks of social capital are likely to be associated with higher probabilities of participation in social organizations by individuals. It is noteworthy that the Trust II regional rate is actually negatively correlated with the individual probability of participation. This is an interesting, although admittedly only suggestive, result because this indicator was constructed on the basis of a survey question that is similar to the commonly used GSS and WVS question on trust. ${ }^{13}$ The correlation between participation and Trust III (which comes from the general question on "distrust") is also negative but it is not significant. Overall, only the trust I question yields the expected and significant positive correlation with individual social participation.

The results presented in tables 5-7 lead to two important conclusions about the determinants of participation in Argentina. First, most of the robust determinants of participation are individual or household characteristics. However, this does not mean that there are no important community-level determinants of participation, since individuals from rural households and those living in provinces with lower unemployment rates have higher probabilities of participation than the rest of the sample. Second, only the trust rate based on Trust I seems to be a reasonable proxy for the stock of social capital. Hence, the survey question used to construct the trust indicator makes a big difference in terms of estimates of its effect on participation. Therefore, the regressions presented in the following sections on trust use Trust I as the dependent variable.

\section{B. Determinants of trust}

\footnotetext{
${ }^{13}$ This result is only suggestive because, although 2235 observations were used to estimate these correlations, there are only six regions. All respondents from the same region have the same "community" trust rates. Hence the
} 
Table 8 shows the basic Probit results for the determinants of the probability that a respondent will answer yes to the Trust I question. Only one of the individual or household characteristics under the second column is slightly significant. That is, the age of the respondent is negative and is significant at the $10 \%$ level. Regarding the community dummy variables, the identifier of rural communities is not significant, and none of the regional dummies are significant.

The third column shows the results with the specification that replaces the income and homeownership variables with the corresponding wealth indicators. The level of wealth is significant at the $5 \%$ level, but its squared term is not significant. However, this linear relationship could be biased due to reverse causality; wealth could be driven by trust. This issue is examined later in this paper. The other significant determinant of trust in this specification is the gender of the respondent; males seem to be more likely to respond in the affirmative than females. Also, one of the region dummies appears significant in this model.

Table 9 shows the results for the model where the regional dummies are replaced with the continuous provincial variables. This model includes wealth instead of income because regressions with the common sample showed that income was not significant. The regression includes the unemployment rate and the relative income ratio. Both provincial or community variables are significant and appear with the expected signs. A one percentage point increase in the provincial unemployment rate (above the sample mean) is associated with a 0.024 decline in the probability of trust by the respondent. The estimated coefficient on the poor's relative income ratio implies that a one percentage point increase in the relative income of the poor in the 
province of residence is associated with a 0.046 increase in the probability of trust by the respondent.

Table 10 examines the mean trust rates by groups of respondents who participate in organizations characterized by their membership homogeneity (using 3 or 4 criteria as discussed earlier) and by the extent of membership participation in three areas: fund management, general decision making, and leadership selection. The calculations presente din this table are the percentage of each sub-sample of participants that responded in the affirmative to the Trust I question. Only the share of those who trusted and participated in organizations with participatory leadership selection procedures was significantly higher than the corresponding share for all participants (i.e., 43.5>39.7\%). This finding provides suggestive evidence indicating that participation in organizations with participatory leader selection procedures are more likely to be associated with higher levels of trust among its membership than other types of social participation.

The estimations discussed so far may suffer from inefficiencies and biases caused by the simultaneity and endogeneity problems discussed above. The following sections analyze results derived from estimations that attempt to control for these potential pitfalls.

\section{Controlling for Simultaneity and Endogeneity: SUR- and TS-Probit Regressions}

Table 11 presents the results from the SUR Probit regressions, which control for the potential correlation between the error terms (or residuals) from both models estimated simultaneously. A first observation is that errors of both models are in fact correlated. This statistic appears at the bottom of Table 11. Second, none of the signs of the coefficients in either 
regression are different from those discussed in reference to Tables 6 and 9. Third, there are a few changes regarding the statistical significance of some of the explanatory variables. In the participation regression, the age and household income variables, which were significant in the previous results, are now even more significant. Also, now the university degree dummy variable appears with the expected positive sign as it did before, but is now slightly significant at the $10 \%$ confidence level. The provincial unemployment rate is no longer a significant determinant of participation. For the trust regression, none of the age variables appear significant at the $10 \%$ level (with opposite signs as those in the participation regression). The absolute value of the Probit coefficients are virtually identical to those previously estimated (but not presented). Hence it seems that there is a significant simultaneity issue affecting these two models, but the correlation between participation and trust mainly affects the precision or efficiency of the estimates, rather than their signs.

Table 12 presents the results from the TS-Probit models estimated separately. The income squared and wealth squared variables were omitted due to this author's inability to estimate models with more than one endogenous variable. Panel A in Table 12 shows the results from the first-stage regressions where the dependent variables were the log of household income (for the participation model) and the household wealth index (for the trust model). The results show that the instruments worked quite well as determinants of both endogenous variables.

Panel B shows the results for the participation and trust regressions once the potentially endogenous variables (household income and wealth, respectively) are instrumented using the household head's age and education characteristics as instruments (as well as all other exogenous variables included in both models). In both cases, there are strong non-linear effects of age, as previously estimated in with the regular Probit and SUR Probit regressions. The exogenous 
component of household income has a strong positive correlation with the probability of participation; and wealth has a strong positive effect on the probability of trust. Residents of rural communities still have a higher probability of participation than others, and the provincial unemployment rate again appears with a slightly significant and negative coefficient in the participation model. In contrast, the probability of trust is still significantly determined by both provincial variables, the unemployment rate and the relative income of the poor. The RiversVuong endogeneity tests indicate that household income was certainly endogenous, while household wealth is not necessarily endogenous. These conclusions are supported by the fact that the errors from the first-stage and the second-stage regressions were significantly correlated only in the models concerning participation, but not for trust.

\section{Conclusions and Policy Implications}

Research on the causes of social capital is in its infancy. This study is one of the first of its kind. It provides an analysis of individual and community characteristics that affect individual decisions related to the accumulation of social capital in a developing country.

This study provided a baseline measurement of indicators of social capital. Argentina is probably on the lower end of social capital when compared to pre-existing international evidence. The results presented here are roughly equivalent to those reported by FLACSO (1997). More importantly, that questions used to measure social capital determined the validity of the empirical indicators of social capital. This is particularly important when measuring interpersonal trust. To nail down this argument, consider the fact that when individuals were asked about their perceptions about whether community members participate in social 
organizations, over $38 \%$ answered in the affirmative. This percentage is almost $100 \%$ higher than the actual participation rate of $19.7 \%$. Future research on social capital should rely on survey questions that inquire about actual behavior, rather than general perceptions derived from ambiguously worded questions.

The main determinants of the probability of participation in Argentina are age, age squared, household income (and perhaps income squared), rural communities (perhaps due to lower probabilities of migration among rural residents, since most migrants live in urban centers), perhaps community or provincial unemployment rates, and the individual's trust itself. In contrast, the main determinants of trust are age and age squared, but with the opposite signs to those exhibited by probability of participation, household wealth (but not its squared term nor household income), participation itself (as demonstrated by the SUR Probit results concerning the cross-correlation between the two social capital models), and especially the community or provincial unemployment rates and income inequality. These results are consistent with the predictions of a simple economic model of the determinants of social capital, where participation is a flow variable, while trust is a stock variable.

Regarding policy implications, one must first assume that raising interpersonal trust and participation in social organizations will have positive effects on economic and social outcomes. To some extent, this assumption has been verified by several empirical studies that were cited in throughout this paper. Hence the question remains of what can be done by policy makers to promote social capital in a developing country such as Argentina. And here is where the empirical analysis of the determinants of social capital is crucial. From the results presented here, we can derive the following general policy recommendations: 
- Economic policies that promote economic growth and employment creation will be associated with increasing individual probabilities of social participation. In turn, higher participation rates will promote interpersonal trust, which itself may stimulate economic growth (Knack and Keefer 1997; Zak and Knack 1998) and reductions in crime (Lederman et al. 2001). However, these existing studies should be interpreted with much care because they rely on the WVS for their trust indicators. In general, therefore, economic reforms that lead to better economic outcomes are likely to be followed by a strengthening of social capital, rather than a weakening of social participation and trust, as is often argued by critics of "neoliberalism."

- Any policies that improve the relative position of the poor in Argentine communities are likely to result in increased interpersonal trust, and hence indirectly will lead to increased social participation. However, policy-makers should keep in mind the fact that economic growth and employment creation also affect social participation and thus indirectly affect trust. Therefore, any policy that attempts to raise the relative position of the poor should aim to be consistent with a pro-growth economic policy.

- Regarding social participation, the results showed specifically that the internal procedures of the organizations could be determinants of the magnitude of the effect that community-level participation rates have on interpersonal trust. Although these results were only suggestive and were based on simple cross-group mean comparisons, the logic of the argument is compelling. Hence, policy-makers attempting to promote the emergence of new social organizations or the involvement of existing organizations in the provision of public services and other projects should make special efforts to promote participatory leadership selection procedures within the organizations. 
There are many remaining issues that merit further analysis. In this study we did not focus on the potential effects of family structure on participation and trust. It is plausible that single parents may have either higher opportunity costs of participation or higher payoffs, if the participation entails sharing parenting responsibilities with other members of the community. Our results on gender were not robust, because its significance depended on whether the specification included the income or the wealth variables. A look at the correlations between the gender of the respondent and the household income and wealth variables reveals that the likelihood that the respondent will be a male is positively correlated with income, but not with wealth. The lack of robustness of the gender variable may be related to some form of selection bias. For example, male heads of household are more likely to be away from home when income flows are important relative to the stock of wealth. Future research could re-examine the link between gender and social capital while controlling for this type of selection bias.

This study found a very weak link between educational attainment and social capital. Namely, the results show very weak evidence that university graduates are more likely to participate than individuals with lower levels of education. Education is not a robust predictor of interpersonal trust. Yet it is likely that the connection between education and social capital is more complicated. Future studies should attempt to fill this gap, perhaps by following Helliwell and Putnam (1999) by using relative educational indicators that measure where the individual stands relative to his/her community's average.

A particularly interesting area for future research is to use the responses to questions about hypothetical shocks faced by individuals and households. For instance, the survey included a question about who the respondent would turn to for assistance when he/she loses her employment or there is a natural catastrophe. In the case of unemployment, $30.6 \%$ of 
respondents said they would have to rely on themselves and 34.4\% said they could rely on neighbors. Very few identified either a particular organization (secular or religious) or a government agency. These data could be used to provide a more colorful picture of why Argentina's social participation rates are so low. Future research could look at correlations between responses to this hypothetical "shock" questions and various individual and household characteristics. 


\section{$\underline{\text { References }}$}

Alesina, Alberto, and Eliana La Ferrara. 2000. "The Determinants of Trust." NBER Working Paper 7621, Cambridge, Massachusetts.

Alesina, Alberto, and Eliana La Ferrara. 1999. "Participation in Heterogenous Communities." NBER Working Paper 7155, Cambridge, Massachusetts.

Arrow, Kenneth. 1971. "Political and Economic Evaluation of Social Effects and Externalities." In Frontiers of Quantitative Economics, edited by M. Intriligator

Bowles, Samuel. 1999. "'Social Capital' and Community Governance." Focus 20(3): 6-10, University of Wisconsin, Madison, Institute for Research on Poverty.

Brehm, John, and Wendy Rahn. 1997. "Individual-Level Evidence for the Causes and Consequences of Social Capital." American Journal of Political Science 41(3): 999-1023.

Coleman, James S. 1990. Foundations of Social Theory. Cambridge, Massachusetts and London, England: Harvard University Press.

Collier, Paul. 1998. "Social Capital and Poverty." Mimeographed. Development Economics Research Group, The World Bank, Washington, DC.

DiPasquale, Denise, and Edward L. Glaeser. 1998. "Incentives and Social Capital: Are Homeowners Better Citizens?" NBER Working Paper 6363, Cambridge, Massachusetts.

Durlauf, Steven N. 1999. "The Case 'Against' Social Capital." Focus 20(3): 1-5, University of Wisconsin, Madison, Institute for Research on Poverty.

FLACSO. 1997. El perfil de las ONGs en la Argentina. Buenos Aires: FLACSO and World Bank.

Glaeser, Edward L., David Laibson, and Bruce Sacerdote. 2000. "The Economic Approach to Social Capital." NBER Working Paper 7728, Cambridge, Massachusetts.

Glaeser, Edward L., David Laibson, Jose A. Scheinkman, and Christine L. Soutter. 1999. "What Is Social Capital? The Determinants of Trust and Trustworthiness." NBER Working Paper 7216, Cambridge, Massachusetts.

Guiso, Luigi, Paola Sapienza, and Luigi Zingales. 2000. "The Role of Social Capital in Financial Development." NBER Working Paper 7563, Cambridge, Massachusetts.

Hassan, Rashid M. 1996. "Planting Strategies of Maize Farmers in Kenya: A Simultaneous Equations Analysis in the Presence of Discrete Dependent Variables." Agricultural Economics 15: 137-149. 
Helliwell, John F., and Robert D. Putnam. 1999. "Education and Social Capital." NBER Working Paper 7121, Cambridge, Massachusetts.

Knack, Stephen, and Phillip Keefer. 1997. "Does Social Capital Have and Economic Payoff? A Cross Country Investigation." Quarterly Journal of Economics 112: 1251-1288.

Lederman, Daniel. 1999. "Crime in Argentina: A Preliminary Assessment." Mimeographed. Office of the Chief Economist for Latin America and the Caribbean, The World Bank, Washington, DC.

Lederman, Daniel, Norman Loayza, and Ana María Menéndez. 2001. "Violent Crime: Does Social Capital Matter?" Mimeographed. Office of the Chief Economist for Latin America and the Caribbean, The World Bank, Washington, DC. Forthcoming in Economic Development and Cultural Change.

Narayan, Deepa. 1997. "Voices of the Poor: Poverty and Social Capital in Tanzania." Environmentally Sustainable Studies and Monograph Series 20. The World Bank, Washington, DC.

Narayan, Deepa, and Lant Pritchett. 1999. "Cents and Sociability: Household Income and Social Capital in Rural Tanzania." Economic Development and Cultural Change 47(4): 871-897.

Newey, Whitney K. 1987. "Efficient Estimation of Limited Dependent Variable Models with Endogenous Explanatory Variables." Journal of Econometrics 36: 231-250.

Norton, Edward C., Richard C. Lindrooth, and Susan T. Ennett. 1998. "Controlling for the Endogeneity of Peer Substance Use on Adolescent Alcohol and Tobacco Use." Health Economics 7: 439-453.

Portes, Alejandro, and Patricia Landolt. 2000. "Social Capital: Promise and Pitfalls of Its Role in Development." Journal of Latin American Studies 32: 529-547.

Putnam, Robert D. 2000. Bowling Alone: The Collapse and Revival of American Community. New York: Simon \& Schuster.

Putnam, Robert D. 1993. Making Democracy Work: Civic Traditions in Modern Italy. Princeton, New Jersey: Princeton University Press.

Ribar, David C. 1994. "Teenage Fertility and High School Completion." Review of Economics and Statistics ???: 413-424.

Rivers, Douglas, and Quang H. Vuong. 1988. "Limited Information Estimators and Exogeneity Tests for Simultaneous Probit Models." Journal of Econometrics 39: 347-366. 
Robison, Lindon, and Marcelo E. Siles. 1997. "Social Capital and Household Income Distribution in the United States: 1980, 1990." Department of Agricultural Economics, Report 595, Michigan State University, Lansing, Michigan.

Rubio, Mauricio. 1997. "Perverse Social Capital -- Some Evidence from Colombia." Journal of Economic Issues 31: 805-816.

Schady, Norbert. 2000. "Who Participates? An Analysis of Volunteering Patterns in Rural Peru." Mimeographed. PREM Network, Latin America and the Caribbean Region, The World Bank, Washington, DC.

Schiff, Maurice. 1999. "Labor Market Integration in the Presence of Social Capital." World Bank Policy Research Working Paper 222. Washington, DC, The World Bank.

Schiff, Maurice. 1992. "Social Capital, Labor Mobility, and Welfare: The Impact of Uniting States." Rationality and Society 4(2): 157-175.

Zak, Paul J., and Stephen Knack. 1998. "Trust and Growth." Mimeographed. Claremont Graduate University, Department of Economics, Claremont, California. 
$\underline{\text { Table 1. Argentina: Participation Rates by Types of Organization }}$

\begin{tabular}{|l|c|}
\hline \multicolumn{1}{|c|}{ Type of Organization } & Participation Rate (\% of sample) \\
\hline Any & 19.7 \\
\hline Homogenous I (3 criteria) & 13.2 \\
\hline Homogenous II (4 criteria) & 9.6 \\
\hline Participatory Leadership Selection & 13.8 \\
\hline Participatory Fund Management & 7.4 \\
\hline Participatory Decision-Making & 13.7 \\
\hline $\begin{array}{l}\text { Source: Author's calculations based on survey data comp iled by Sofres-Ibope, Argentina. See text for } \\
\text { definitions. }\end{array}$ \\
\hline
\end{tabular}

Table 2. Participation Rates by Organizational Types in Argentine Regions

\begin{tabular}{|l|c|c|c|c|c|c|}
\hline $\begin{array}{l}\text { Type of } \\
\text { Organiz. }\end{array}$ & $\begin{array}{l}\text { Region 1: } \\
\text { Metropol. }\end{array}$ & $\begin{array}{l}\text { Region 2: } \\
\text { Central }\end{array}$ & $\begin{array}{l}\text { Region 3: } \\
\text { Northeast }\end{array}$ & $\begin{array}{l}\text { Region 4: } \\
\text { Cuyo }\end{array}$ & $\begin{array}{l}\text { Region 5: } \\
\text { N.-west }\end{array}$ & $\begin{array}{l}\text { Region 6: } \\
\text { South }\end{array}$ \\
\hline Any & 14.5 & 21.3 & 20.9 & 22.4 & 19.4 & 26.3 \\
\hline Homog. I & 10.3 & 13.8 & 11.4 & 16.4 & 14.9 & 14.6 \\
\hline Homog. II & 7.5 & 10.2 & 7.1 & 14.4 & 9.5 & 10.1 \\
\hline Part. Lead. & 11.1 & 13.8 & 14.1 & 15.2 & 13.8 & 18.9 \\
\hline Part. Fund & 3.8 & 8.2 & 7.7 & 8.9 & 8.0 & 12.1 \\
\hline Part. Dmk. & 10.1 & 12.7 & 15.5 & 17.2 & 13.8 & 18.2 \\
\hline
\end{tabular}

Source: Author's calculations based on survey data compiled by Sofres-Ibope, Argentina. See text for definitions.

Regional Codes by Settlements (provinces in parenthesis):

Region 1 - Metropolitan: Federal Capital and Sub-urban Buenos Aires

Region 2 - Central: Rancul (La Pampa); Cordoba (Cordoba); Rosario (Santa Fe); La Plata (B.A.); Mar del

Plata (B.A.); Santa Fe (Santa Fe); Bahia Blanca (B.A.); Parana (Entre Rios); Larroque (Entre Rios); Rio

Cuarto (Cordoba)

Region 3 - Northeast: Resistencia (Chaco); Charata (Chaco); Corrientes (Corrientes); Posadas (Misiones); San Javier (Misiones); Formosa (Formosa)

Region 4 - Cuyo: Mendoza (Mendoza); Tupungato (Mendoza); San Juan (San Juan); Villa Aberastarain (San Juan); San Luis (San Luis)

Region 5 - Northwest: San Miguel (Tucuman); Salta (Salta); Santiago del Estero (Santiago del Estero); San Salvador (Jujuy); San Fernando del Valle (Catamarca); Chumbicha (Catamarca); La Rioja (La Rioja);

Fatima (La Rioja)

Region 6 - South: Neuquen (Neuquen); Piedra del Aguila (Neuquen); Bariloche (Rio Negro); Luis Beltran (Rio Negro); Comodoro Rivadavia (Chubut) 
Table 3. Trust in Argentina by Types of Trust Question

\begin{tabular}{|l|c|}
\hline Trust Indicator & $\begin{array}{c}\text { Trust "Rate" } \\
\text { (\% of respondents answering in the affirmative) }\end{array}$ \\
\hline I & 33.1 \\
\hline II & 66.8 \\
\hline III & 57.7 \\
\hline $\begin{array}{l}\text { Source: Author's calculations based on survey data compiled by Sofres-Ibope, Argentina. See text for } \\
\text { definitions. }\end{array}$ \\
\hline
\end{tabular}

Table 4. Trust Rates by Types of Trust Question in Argentine Regions

\begin{tabular}{|l|c|c|c|l|l|c|}
\hline $\begin{array}{l}\text { Type of } \\
\text { "Trust" }\end{array}$ & $\begin{array}{l}\text { Region 1: } \\
\text { Metropol. }\end{array}$ & $\begin{array}{l}\text { Region 2: } \\
\text { Central }\end{array}$ & $\begin{array}{l}\text { Region 3: } \\
\text { Northeast }\end{array}$ & $\begin{array}{l}\text { Region 4: } \\
\text { Cuyo }\end{array}$ & $\begin{array}{l}\text { Region 5: } \\
\text { N.-west }\end{array}$ & $\begin{array}{l}\text { Region 6: } \\
\text { South }\end{array}$ \\
\hline I & 28.9 & 37.4 & 27.3 & 47.4 & 22.9 & 37.9 \\
\hline II & 70.3 & 63.5 & 73.7 & 64.4 & 66.2 & 59.1 \\
\hline III & 58.5 & 58.3 & 62.3 & 42.8 & 67.3 & 56.6 \\
\hline
\end{tabular}

Source: Author's calculations based on survey data compiled by Sofres-Ibope, Argentina. See text for definitions.

$\underline{\text { Regional Codes by Settlements (provinces in parenthesis): }}$

Region 1 - Metropolitan: Federal Capital and Sub-urban Buenos Aires

Region 2 - Central: Rancul (La Pampa); Cordoba (Cordoba); Rosario (Santa Fe); La Plata (B.A.); Mar del

Plata (B.A.); Santa Fe (Santa Fe); Bahia Blanca (B.A.); Parana (Entre Rios); Larroque (Entre Rios); Rio Cuarto (Cordoba)

Region 3 - Northeast: Resistencia (Chaco); Charata (Chaco); Corrientes (Corrientes); Posadas (Misiones); San Javier (Misiones); Formosa (Formosa)

Region 4 - Cuyo: Mendoza (Mendoza); Tupungato (Mendoza); San Juan (San Juan); Villa Aberastarain (San Juan); San Luis (San Luis)

Region 5 - Northwest: San Miguel (Tucuman); Salta (Salta); Santiago del Estero (Santiago del Estero); San Salvador (Jujuy); San Fernando del Valle (Catamarca); Chumbicha (Catamarca); La Rioja (La Rioja); Fatima (La Rioja)

Region 6 - South: Neuquen (Neuquen); Piedra del Aguila (Neuquen); Bariloche (Rio Negro); Luis Beltran (Rio Negro); Comodoro Rivadavia (Chubut) 
Table 5. The Determinants of Participation in Argentina: Basic Probit Results (dependent variable: individual's probability of participation in any social organization)

\begin{tabular}{|c|c|c|}
\hline Explanatory Variable & $\begin{array}{c}\text { Marginal Probit } \\
\text { Coefficients (a) (b) }\end{array}$ & $\begin{array}{c}\text { Marginal Probit } \\
\text { Coefficients (a) (b) }\end{array}$ \\
\hline \multicolumn{3}{|c|}{ Individual - Household Characteristics: continuous variables } \\
\hline Age of respondent (c) & $\begin{array}{c}0.008 * * \\
(0.002) \\
\end{array}$ & $\begin{array}{c}0.009 * * \\
(0.002)\end{array}$ \\
\hline $\operatorname{Age}^{\wedge} 2$ & $\begin{array}{c}-0.000 * * \\
(0.000)\end{array}$ & $\begin{array}{l}-0.000 * * \\
(0.000)\end{array}$ \\
\hline $\begin{array}{l}\text { Ln(Income per capita of household) } \\
\text { (c) }\end{array}$ & $\begin{array}{c}-0.114 * * \\
(0.054)\end{array}$ & $\begin{array}{c}0.008 \\
(0.013)(\mathbf{d})\end{array}$ \\
\hline $\operatorname{Ln}(\text { Income per capita household })^{\wedge} 2$ & $\begin{array}{c}0.012 * * \\
(0.006) \\
\end{array}$ & $\begin{array}{c}0.007 \\
(0.008)(\mathbf{d}) \\
\end{array}$ \\
\hline \multicolumn{3}{|c|}{ Individual - Household Characteristics: dummy variables } \\
\hline Unemployed head of household & $\begin{array}{c}-0.078 * * \\
(0.030)\end{array}$ & $\begin{array}{c}-0.079 * * \\
(0.028)\end{array}$ \\
\hline Male respondent & $\begin{array}{l}-0.025^{*} \\
(0.013)\end{array}$ & $\begin{array}{c}-0.021 \\
(0.014)\end{array}$ \\
\hline Home owned by household & $\begin{array}{c}-0.008 \\
(0.022) \\
\end{array}$ & Not included \\
\hline $\begin{array}{l}\text { Finished Primary } \\
\text { (education of respondent) }\end{array}$ & $\begin{array}{r}0.009 \\
(0.035) \\
\end{array}$ & $\begin{array}{c}0.007 \\
(0.034) \\
\end{array}$ \\
\hline $\begin{array}{l}\text { Finished Secondary } \\
\text { (education of respondent) }\end{array}$ & $\begin{array}{c}0.009 \\
(0.038) \\
\end{array}$ & $\begin{array}{c}0.009 \\
(0.037) \\
\end{array}$ \\
\hline $\begin{array}{l}\text { Finished Tertiary } \\
\text { (education of respondent) }\end{array}$ & $\begin{array}{c}0.062 \\
(0.046) \\
\end{array}$ & $\begin{array}{c}0.061 \\
(0.045) \\
\end{array}$ \\
\hline $\begin{array}{l}\text { University Degree } \\
\text { (education of respondent) }\end{array}$ & $\begin{array}{c}0.081 \\
(0.064)\end{array}$ & $\begin{array}{l}0.121 * * \\
(0.066)\end{array}$ \\
\hline \multicolumn{3}{|c|}{ Community (Regional) Dummies } \\
\hline Rural & $\begin{array}{l}0.089 * * \\
(0.038)\end{array}$ & $\begin{array}{l}0.097 * * \\
(0.036)\end{array}$ \\
\hline Region 1 & $\begin{array}{c}-0.097 * * \\
(0.042)\end{array}$ & $\begin{array}{c}-0.104 * * \\
(0.039)\end{array}$ \\
\hline Region 2 & $\begin{array}{l}-0.035 \\
(0.039)\end{array}$ & $\begin{array}{c}-0.038 \\
(0.035) \\
\end{array}$ \\
\hline Region 3 & $\begin{array}{c}-0.032 \\
(0.058) \\
\end{array}$ & $\begin{array}{l}-0.037 \\
(0.053) \\
\end{array}$ \\
\hline Region 4 & $\begin{array}{c}-0.028 \\
(0.041)\end{array}$ & $\begin{array}{l}-0.033 \\
(0.036)\end{array}$ \\
\hline Region 5 & $\begin{array}{c}-0.054 \\
(0.040)\end{array}$ & $\begin{array}{l}-0.064 * \\
(0.036)\end{array}$ \\
\hline $\begin{array}{l}\text { Observations } \\
\text { Pseudo } \mathrm{R}^{\wedge} 2 \\
\text { Predicted Sample Probability }\end{array}$ & $\begin{array}{c}2235 \\
0.028 \\
19.1 \% \\
\text { (Actual }=19.7 \% \text { ) }\end{array}$ & $\begin{array}{c}2187 \\
0.031 \\
19.2 \% \\
\text { (Actual }=19.9 \% \text { ) }\end{array}$ \\
\hline
\end{tabular}

(a) Reported coefficients are "marginal" effects. For dummy variables, they show the effect of a change from 0 to 1 . (b) Standard errors (in parentheses) corrected for heteroskedasticity and clustering of the residuals at the settlement level.

(c) The marginal coefficients of age and income are not the ones presented in this table; see text.

(d) The wealth index is used instead of the natural logarithm of current household income per capita and homeownership variables.

$* *=$ significant at $5 \%$ level; $*$ = significant at $10 \%$ level. 
Table 6. The Determinants of Participation in Argentina:

Probit Results with Continuous Explanatory Community Variables (dependent variable: individual's probability of participation in any social organization)

\begin{tabular}{|l|c|}
\hline Explanatory Variable (a) (b) & \\
\hline $\begin{array}{l}\text { Controls for individuat household } \\
\text { characteristis? }\end{array}$ & Yes \\
\hline $\begin{array}{l}\text { Results changed for individual } \\
\text { household characateristics? }\end{array}$ & No \\
\hline Rural & $0.102^{* *}$ \\
& $(0.035)$ \\
\hline Provincial Unemployment Rate & $-0.008^{* *}$ \\
& $(0.004)$ \\
\hline $\begin{array}{l}\text { Ratio of Income Shares } \\
\text { (poorest quintile / richest quintile) }\end{array}$ & 0.014 \\
\hline Observations & 2235 \\
\hline Pseudo R^2 & 0.022 \\
\hline $\begin{array}{l}\text { Predicted Sample Probability } \\
\text { (Actual = 19.7\%) }\end{array}$ & $19.1 \%$ \\
\hline
\end{tabular}

(a) Reported coefficients are "marginal" effects. For dummy variables, they show the effect of a change from 0 to 1 . (b) Standard errors of the underlying Probit coefficients (in parentheses) are corrected for heteroskedasticity and clustering of the errors at the settlement level.

$* *=$ significant at $5 \%$ level; $*$ significant at $10 \%$ level.

Table 7. Correlations between Individual Participation and Community Trust Rates (dependent variable: individual's probability of participation in any social organization)

\begin{tabular}{|l|c|}
\hline $\begin{array}{l}\text { Community Trust Rate } \\
\text { (see text for definitions) }\end{array}$ & $\begin{array}{c}\text { Correlation Coefficient } \\
\text { (p-value) }\end{array}$ \\
\hline Type I & $0.049^{* *}$ \\
& $(0.020)$ \\
\hline Type II & $-0.061^{* *}$ \\
& $(0.004)$ \\
\hline Type III & -0.026 \\
\multicolumn{2}{|c|}{$(0.220)$} \\
\hline
\end{tabular}

** = significant at $5 \%$ level. 
Table 8. The Determinants of Interpersonal Trust in Argentina: Basic Probit Results (dependent variable: individual's probability of answering yes to the Trust I question)

\begin{tabular}{|c|c|c|}
\hline Explanatory Variable & $\begin{array}{c}\text { Marginal Probit } \\
\text { Coefficients (a) (b) }\end{array}$ & $\begin{array}{c}\text { Marginal Probit } \\
\text { Coefficients (a) (b) }\end{array}$ \\
\hline \multicolumn{3}{|c|}{ Individual - Household Characteristics: continuous variables } \\
\hline Age of respondent (c) & $\begin{array}{l}-0.004 * \\
(0.002)\end{array}$ & $\begin{array}{l}-0.004 * \\
(0.002)\end{array}$ \\
\hline $\operatorname{Age}^{\wedge} 2$ & $\begin{array}{r}0.000 \\
(0.000) \\
\end{array}$ & $\begin{array}{l}0.000^{*} \\
(0.000) \\
\end{array}$ \\
\hline $\begin{array}{l}\text { Ln(Income per capita of household) } \\
\text { (c) }\end{array}$ & $\begin{array}{c}0.128 \\
(0.099)\end{array}$ & $\begin{array}{c}0.038 * * \\
(0.016)(\mathbf{d})\end{array}$ \\
\hline $\operatorname{Ln}(\text { Income per capita household })^{\wedge} 2$ & $\begin{array}{c}-0.006 \\
(0.010)\end{array}$ & $\begin{array}{c}-0.012 \\
(0.011)(\mathbf{d})\end{array}$ \\
\hline \multicolumn{3}{|c|}{ Individual - Household Characteristics: dummy variables } \\
\hline Unemployed head of household & $\begin{array}{c}0.054 \\
(0.049) \\
\end{array}$ & $\begin{array}{c}0.018 \\
(0.045) \\
\end{array}$ \\
\hline Victim of crime in the household & $\begin{array}{l}-0.007 \\
(0.025)\end{array}$ & $\begin{array}{l}-0.005 \\
(0.025) \\
\end{array}$ \\
\hline Male respondent & $\begin{array}{c}0.030 \\
(0.023) \\
\end{array}$ & $\begin{array}{l}0.045 * * \\
(0.022)\end{array}$ \\
\hline Home owned by household & $\begin{array}{c}0.001 \\
(0.025) \\
\end{array}$ & Not included \\
\hline $\begin{array}{l}\text { Finished Primary } \\
\text { (education of respondent) }\end{array}$ & $\begin{array}{c}-0.039 \\
(0.035)\end{array}$ & $\begin{array}{c}-0.031 \\
(0.035)\end{array}$ \\
\hline $\begin{array}{l}\text { Finished Secondary } \\
\text { (education of respondent) }\end{array}$ & $\begin{array}{c}0.022 \\
(0.035) \\
\end{array}$ & $\begin{array}{c}0.045 \\
(0.033) \\
\end{array}$ \\
\hline $\begin{array}{l}\text { Finished Tertiary } \\
\text { (education of respondent) }\end{array}$ & $\begin{array}{c}0.013 \\
(0.051)\end{array}$ & $\begin{array}{c}0.039 \\
(0.050)\end{array}$ \\
\hline $\begin{array}{l}\text { University Degree } \\
\text { (education of respondent) }\end{array}$ & $\begin{array}{c}0.031 \\
(0.056) \\
\end{array}$ & $\begin{array}{c}0.040 \\
(0.064) \\
\end{array}$ \\
\hline \multicolumn{3}{|c|}{ Community (Regional) Dummies } \\
\hline Rural & $\begin{array}{c}-0.026 \\
(0.040) \\
\end{array}$ & $\begin{array}{c}-0.032 \\
(0.044) \\
\end{array}$ \\
\hline Region 1 & $\begin{array}{l}-0.097 \\
(0.077) \\
\end{array}$ & $\begin{array}{l}-0.101 \\
(0.075) \\
\end{array}$ \\
\hline Region 2 & $\begin{array}{c}0.013 \\
(0.090) \\
\end{array}$ & $\begin{array}{c}-0.010 \\
(0.086) \\
\end{array}$ \\
\hline Region 3 & $\begin{array}{c}-0.066 \\
(0.081)\end{array}$ & $\begin{array}{l}-0.095 \\
(0.075)\end{array}$ \\
\hline Region 4 & $\begin{array}{c}0.116 \\
(0.091)\end{array}$ & $\begin{array}{c}0.082 \\
(0.087)\end{array}$ \\
\hline Region 5 & $\begin{array}{c}-0.124 \\
(0.076) \\
\end{array}$ & $\begin{array}{l}-0.149 * \\
(0.070)\end{array}$ \\
\hline $\begin{array}{l}\text { Observations } \\
\text { Pseudo } \mathrm{R}^{\wedge} 2 \\
\text { Predicted Sample Probability }\end{array}$ & $\begin{array}{c}2235 \\
0.042 \\
32.4 \% \\
\text { (Actual }=33.1 \% \text { ) }\end{array}$ & $\begin{array}{c}2187 \\
0.034 \\
32.3 \% \\
\text { (Actual }=32.9 \% \text { ) } \\
\end{array}$ \\
\hline
\end{tabular}

(a) Reported coefficients are "marginal" effects. For dummy variables, they show the effect of a change from 0 to 1. (b) Standard errors of the underlying Probit coefficients (in parentheses) are corrected for heteroskedasticity and clustering of the residuals at the settlement level.

(c) The marginal coefficients of age and income are not the ones presented in this table; see text.

(d) The wealth index is used instead of the natural logarithm of the household income per capita and homeownership variables.

$* *=$ significant at $5 \%$ level; $*=$ significant at $10 \%$ level. 
Table 9. The Determinants of Interpersonal Trust in Argentina:

Probit Results with Continuous Explanatory Community Variables

(dependent variable: individual's probability of answering yes to the Trust I question)

\begin{tabular}{|l|c|}
\hline Explanatory Variable (a) (b) & Yes \\
\hline $\begin{array}{l}\text { Controls for individuathousehold } \\
\text { characteristics, including wealth? }\end{array}$ & No \\
\hline $\begin{array}{l}\text { Results changed for individual \& } \\
\text { household characteristics? }\end{array}$ & Not sig. \\
\hline Rural & $\begin{array}{c}-0.024^{* *} \\
(0.005)\end{array}$ \\
\hline Provincial Unemployment Rate & $\begin{array}{c}0.046^{* *} \\
(1.304)\end{array}$ \\
\hline $\begin{array}{l}\text { Provincial Ratio of Income Shares } \\
\text { (poorest quintile / richest quintile) }\end{array}$ & 2187 \\
\hline Observations & 0.031 \\
\hline Pseudo R^2 & $32.4 \%$ \\
\hline $\begin{array}{l}\text { Predicted Sample Probability } \\
\text { (Actual = 32.9\%) }\end{array}$ \\
\hline
\end{tabular}

(a) Reported coefficients are "marginal" effects. For dummy variables, they show the effect of a change from 0 to 1. (b) Standard errors (in parentheses) corrected for heteroskedasticity and clustering of the residuals at the settlement level.

$* *=$ significant at $5 \%$ level; $*$ significant at $10 \%$ level.

$\underline{\text { Table 10. Trust (I) Rates in Groups of Participants }}$

\begin{tabular}{|c|c|}
\hline $\begin{array}{c}\text { Participation Types -- see text for definitions } \\
\text { (observations) }\end{array}$ & $\begin{array}{l}\text { Trust Rate, \% of participants } \\
(95 \% \text { confidence interval) }\end{array}$ \\
\hline $\begin{array}{l}\text { Participation of Any Type } \\
(441)\end{array}$ & $\begin{array}{c}39.7 \\
(35.1-44.3)\end{array}$ \\
\hline $\begin{array}{l}\text { Homogenous Membership I } \\
\text { (295) }\end{array}$ & $\begin{array}{c}38.3 \\
(32.7-43.9)\end{array}$ \\
\hline $\begin{array}{l}\text { Homogenous Membership II } \\
\text { (214) }\end{array}$ & $\begin{array}{c}39.7 \\
(33.1-46.3)\end{array}$ \\
\hline $\begin{array}{l}\text { Fund Management } \\
\text { (165) }\end{array}$ & $\begin{array}{c}38.8 \\
(31.3-46.3)\end{array}$ \\
\hline $\begin{array}{c}\text { Decision Making } \\
\text { (307) }\end{array}$ & $\begin{array}{c}39.7 \\
(34.2-45.2)\end{array}$ \\
\hline $\begin{array}{l}\text { Leadership Selection** } \\
\text { (308) }\end{array}$ & $\begin{array}{c}43.5 \\
(37.9-49.1)\end{array}$ \\
\hline
\end{tabular}

** significantly different from other participants at 5\% 
Table 11. SUR Probit Regressions on Participation and Trust (I)

\begin{tabular}{|c|c|c|}
\hline Explanatory Variable & $\begin{array}{c}\text { Participation } \\
\text { Probit Coefficients (a) }\end{array}$ & $\begin{array}{c}\text { Trust (I) } \\
\text { Probit Coefficients (a) } \\
\end{array}$ \\
\hline \multicolumn{3}{|c|}{ Individual - Household Characteristics: continuous variables } \\
\hline Age of respondent & $\begin{array}{l}0.031 * * \\
(0.009)\end{array}$ & $\begin{array}{l}-0.012 * \\
(0.002)\end{array}$ \\
\hline $\operatorname{Age}^{\wedge} 2$ & $\begin{array}{c}-0.000 * * \\
(0.000) \\
\end{array}$ & $\begin{array}{l}0.000^{*} \\
(0.000) \\
\end{array}$ \\
\hline Ln(Income per capita of household) & $\begin{array}{c}-0.442 * * \\
(0.208)\end{array}$ & $\begin{array}{c}0.107 * * \\
(0.017)(\mathbf{b}) \\
\end{array}$ \\
\hline $\operatorname{Ln}(\text { Income per capita household })^{\wedge} 2$ & $\begin{array}{l}0.044 * * \\
(0.021)\end{array}$ & $\begin{array}{c}-0.033 \\
(0.030)(\mathbf{b})\end{array}$ \\
\hline \multicolumn{3}{|c|}{ Individual - Household Characteristics: dummy variables } \\
\hline Unemployed head of household & $\begin{array}{c}-0.367 * * \\
(0.154) \\
\end{array}$ & $\begin{array}{c}0.049 \\
(0.120) \\
\end{array}$ \\
\hline Victim of Crime in the household & Not included & $\begin{array}{l}-0.005 \\
(0.070) \\
\end{array}$ \\
\hline Male respondent & $\begin{array}{l}-0.069 \\
(0.048) \\
\end{array}$ & $\begin{array}{l}0.120 * * \\
(0.023) \\
\end{array}$ \\
\hline Home owned by household & $\begin{array}{l}-0.055 \\
(0.082) \\
\end{array}$ & Not included \\
\hline $\begin{array}{l}\text { Finished Primary } \\
\text { (education of respondent) }\end{array}$ & $\begin{array}{c}0.008 \\
(0.128) \\
\end{array}$ & $\begin{array}{c}-0.072 \\
(0.099) \\
\end{array}$ \\
\hline $\begin{array}{l}\text { Finis hed Secondary } \\
\text { (education of respondent) }\end{array}$ & $\begin{array}{c}0.024 \\
(0.149) \\
\end{array}$ & $\begin{array}{c}0.138 \\
(0.089) \\
\end{array}$ \\
\hline $\begin{array}{l}\text { Finished Tertiary } \\
\text { (education of respondent) }\end{array}$ & $\begin{array}{c}0.223 \\
(0.156) \\
\end{array}$ & $\begin{array}{c}0.109 \\
(0.133) \\
\end{array}$ \\
\hline $\begin{array}{l}\text { University Degree } \\
\text { (education of respondent) }\end{array}$ & $\begin{array}{l}0.381 * \\
(0.210) \\
\end{array}$ & $\begin{array}{c}0.114 \\
(0.164) \\
\end{array}$ \\
\hline \multicolumn{3}{|c|}{ Community ( \& Provincial) Variables } \\
\hline Rural & $\begin{array}{l}0.364 * * \\
(0.103) \\
\end{array}$ & $\begin{array}{l}-0.121 \\
(0.048) \\
\end{array}$ \\
\hline Unemployment Rate (Province) & $\begin{array}{c}-0.082 \\
(0.078)\end{array}$ & $\begin{array}{c}-0.067 * * \\
(0.015)\end{array}$ \\
\hline Ratio of Income Shares (Province) & $\begin{array}{c}0.000 \\
(0.092) \\
\end{array}$ & $\begin{array}{l}0.129 * * \\
(3.520) \\
\end{array}$ \\
\hline Observations & 2187 & 2187 \\
\hline $\begin{array}{l}\text { Error Correlation } \\
\text { (p-value) }\end{array}$ & \multicolumn{2}{|c|}{$\begin{array}{c}0.131 * * \\
(0.044) \\
\end{array}$} \\
\hline
\end{tabular}

(a) Standard errors (in parentheses) corrected for heteroskedasticity and clustering of the residuals at the settlement level.

(b) The wealth index is used instead of the natural logarithm of the household income per capita and homeownership variables.

Note: Regression included intercepts for both dependent variables.

** significant at $5 \%$ level, * significant at $10 \%$ level 
$\underline{\text { Table 12. Two-Stage Probit Regressions on Participation and Trust }}$

\begin{tabular}{|c|c|c|}
\hline Explanatory Variables & Participation & Trust (I) \\
\hline \multicolumn{3}{|c|}{ Dependent Variables are Ln(Household Income) and Household Wealth Index } \\
\hline Education yrs. of head of household & $0.392 * *$ & $0.064 * *$ \\
\hline Education yrs. head of household^2 & $-0.046^{* *}$ & $-0.001 * *$ \\
\hline Age of head of household & $0.016^{*}$ & $0.376 * *$ \\
\hline Age of head of household^2 & -0.000 & $-0.046 * *$ \\
\hline Age of respondent & -0.009 & -0.009 \\
\hline Age of respondent^ 2 & $0.000 * *$ & 0.000 \\
\hline Victim of crime in household & Not included & $0.088 *$ \\
\hline Male respondent & $0.169 * *$ & -0.061 \\
\hline Finished primary (respondent) & $0.391 * *$ & $0.296 * *$ \\
\hline Finished secondary (respondent) & $0.751 * *$ & $0.730 * *$ \\
\hline Finished tertiary (respondent) & $0.974 * *$ & $1.053 * *$ \\
\hline University degree (respondent) & $1.242 * *$ & $1.283 * *$ \\
\hline Unemployed head of household & $-0.611 * *$ & $-0.386 * *$ \\
\hline Home owned by household & -0.000 & Not included \\
\hline Rural community & $-0.188 * *$ & $-0.235 * *$ \\
\hline Provincial unemployment rate & $0.024 * *$ & $0.018 *$ \\
\hline $\begin{array}{l}\text { Provincial ratio of income shares } \\
\text { (poorest quintile / richest quintile) }\end{array}$ & $0.065 * *$ & 0.028 \\
\hline Intercept & $2.351 * *$ & $-2.983 * *$ \\
\hline \multicolumn{3}{|c|}{$\begin{array}{l}\text { B. Second-Stage Regressions: } \\
\text { Dependent Variables are Individual Participation and Trust (I) }\end{array}$} \\
\hline Age of respondent & $0.026 * *$ & $-0.033 * *$ \\
\hline Age of respondent^ 2 & $-0.000^{*}$ & $0.000 * *$ \\
\hline Ln(household income) & $0.475 * *$ & $0.358 * *$ (a) \\
\hline Victim of crime in household & Note included & 0.103 \\
\hline Male respondent & 0.000 & -0.045 \\
\hline Finished primary (respondent) & -0.217 & -0.133 \\
\hline Finished secondary (respondent) & -0.389 & -0.094 \\
\hline Finished tertiary (respondent) & -0.359 & -0.184 \\
\hline University degree (respondent) & -0.337 & -0.132 \\
\hline Unemployed head of household & 0.221 & -0.046 \\
\hline Home owned by household & -0.103 & Not included \\
\hline Rural community & $0.340 * *$ & 0.146 \\
\hline Provincial unemployment rate & $-0.030^{*}$ & $-0.080 * *$ \\
\hline $\begin{array}{l}\text { Provincial ratio of income shares } \\
\text { (poorest quintile / richest quintile) }\end{array}$ & -0.015 & $0.107 * *$ \\
\hline Intercept & -2.879 & 0.105 \\
\hline Observations & 1159 & 1159 \\
\hline Error Correlation & $-0.377 * *$ & -0.194 \\
\hline $\begin{array}{l}\text { Rivers-Vuong Endogeneity Test } \\
\text { (p-value) }\end{array}$ & $0.016 * *$ & 0.186 \\
\hline
\end{tabular}

(a) Wealth index included in trust regression instead of household income $* *$ significant at $5 \%$, $*$ significant at $10 \%$ 
Figure 1. Causal Relationships among Social Participation, Trust and Confidence in Public Institutions

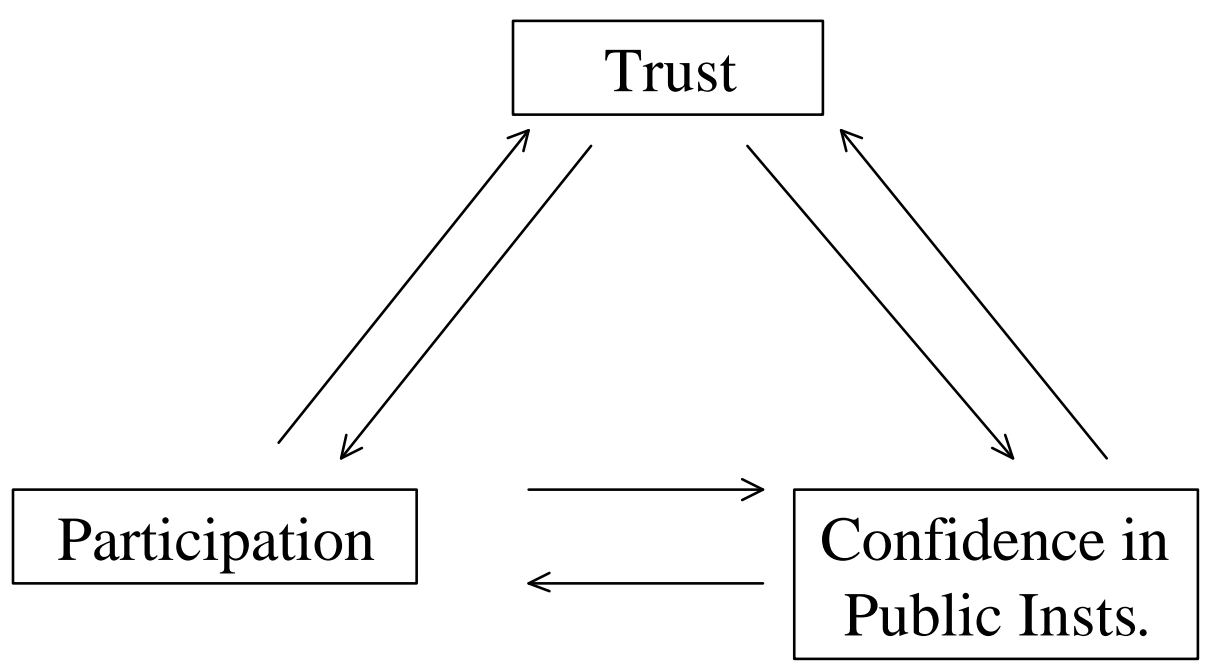

Source: Brehm and Rahn $(1997,1002)$. 
Figure 2. Participation Rates by Income per Capita Deciles

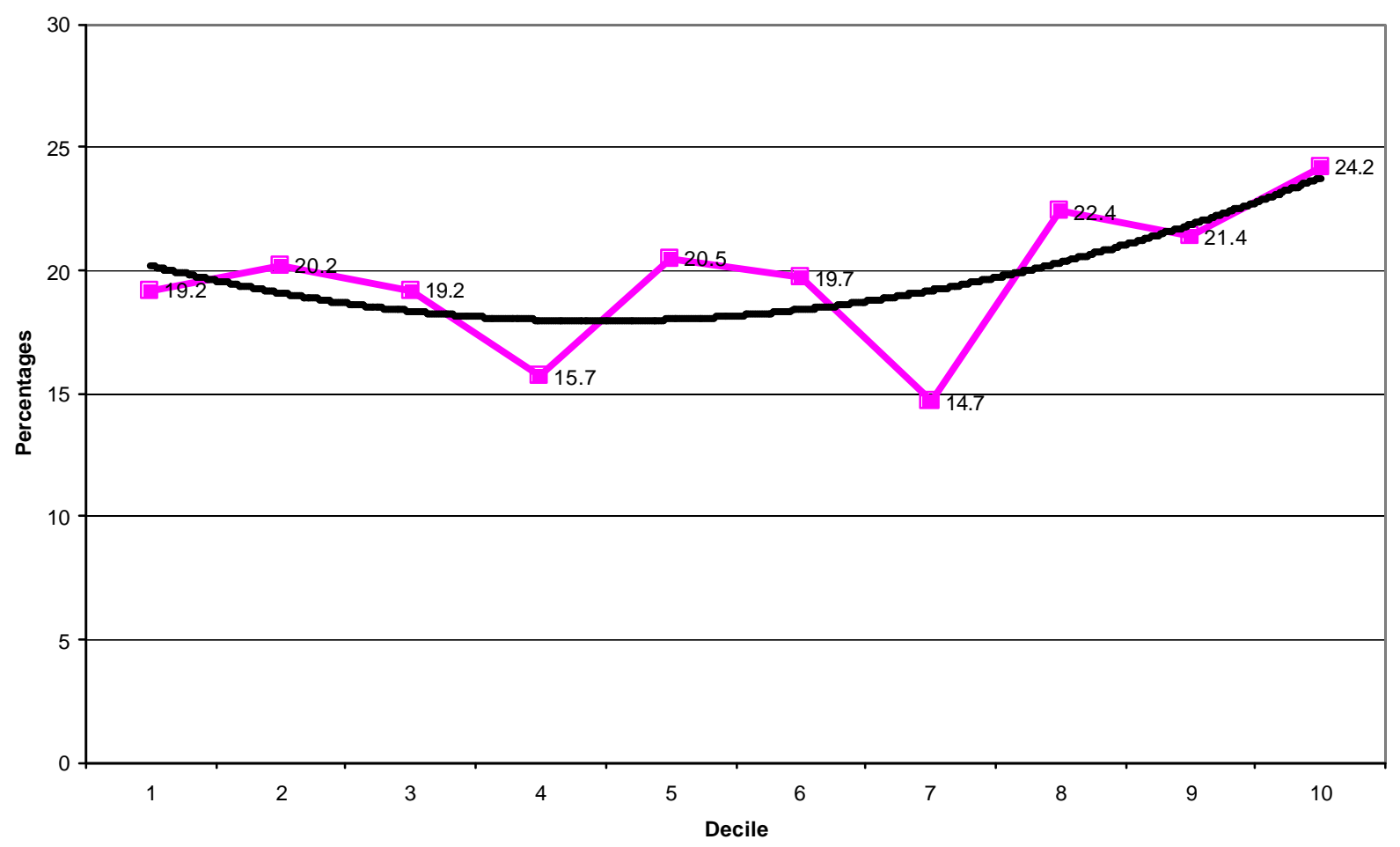

Figure 3. Trust Rates by Wealth Deciles

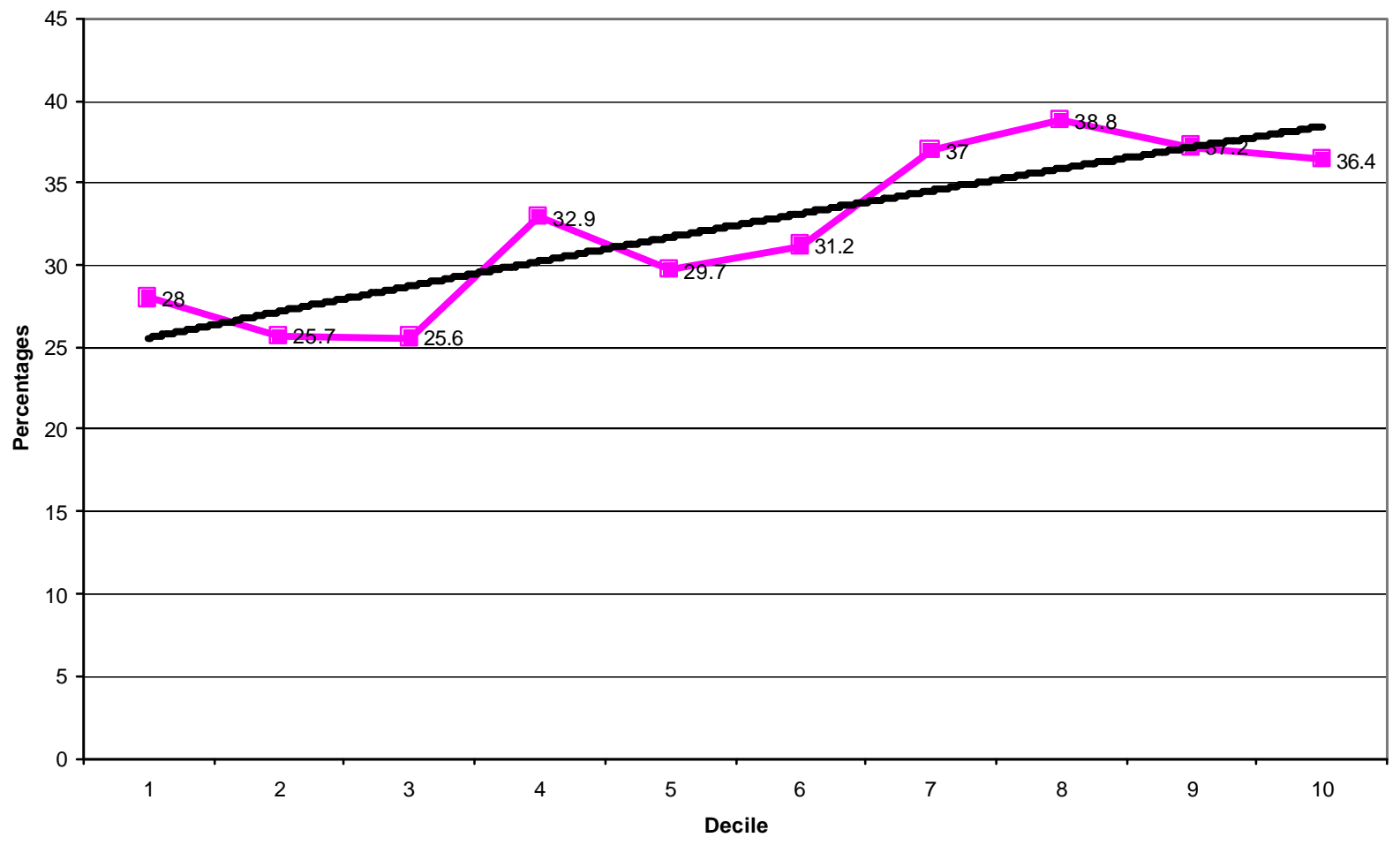


Figure 4. The Marginal Effect of Age Varies across the Population

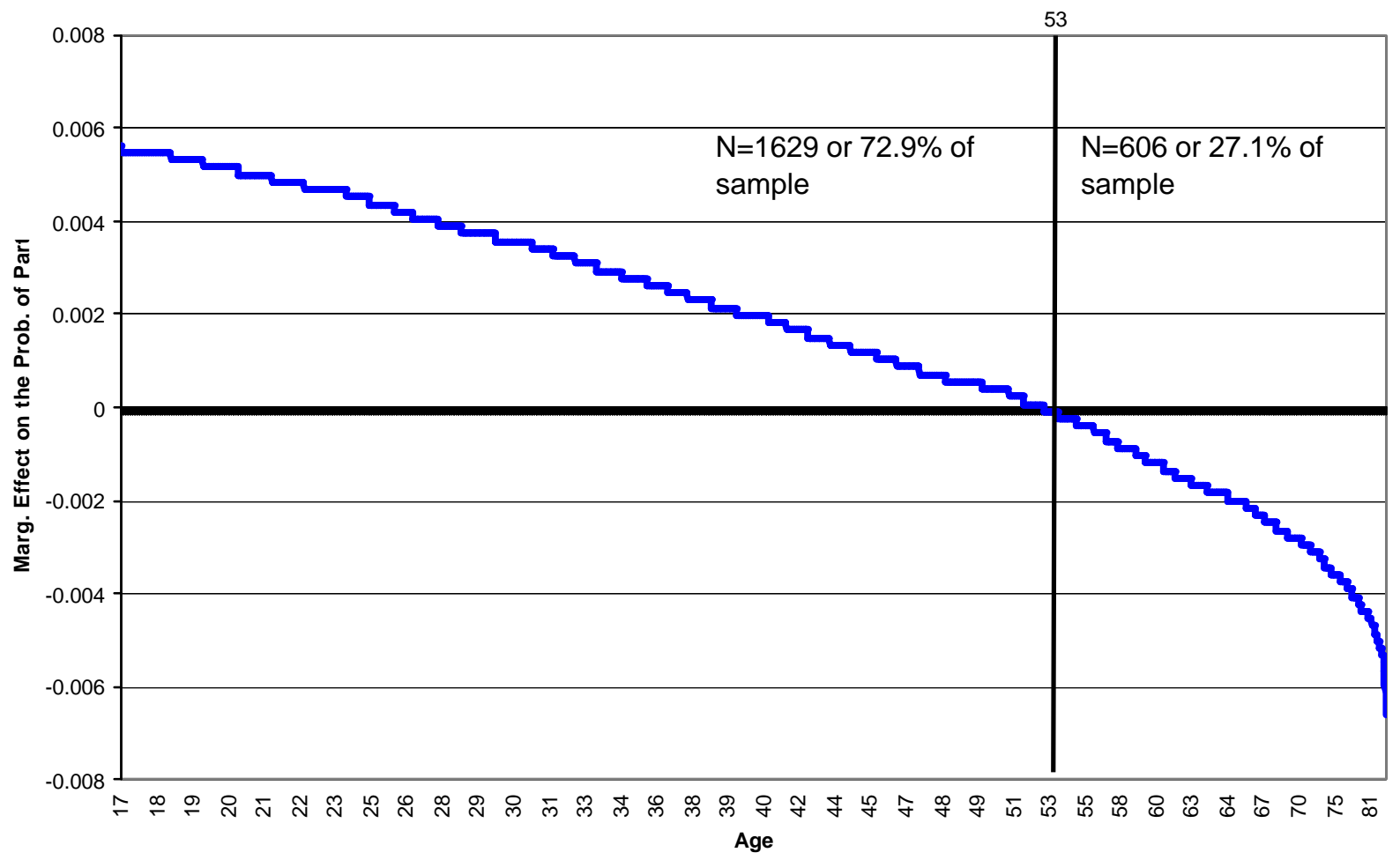

Figure 5. The Marginal Effect of Income Varies across the Population

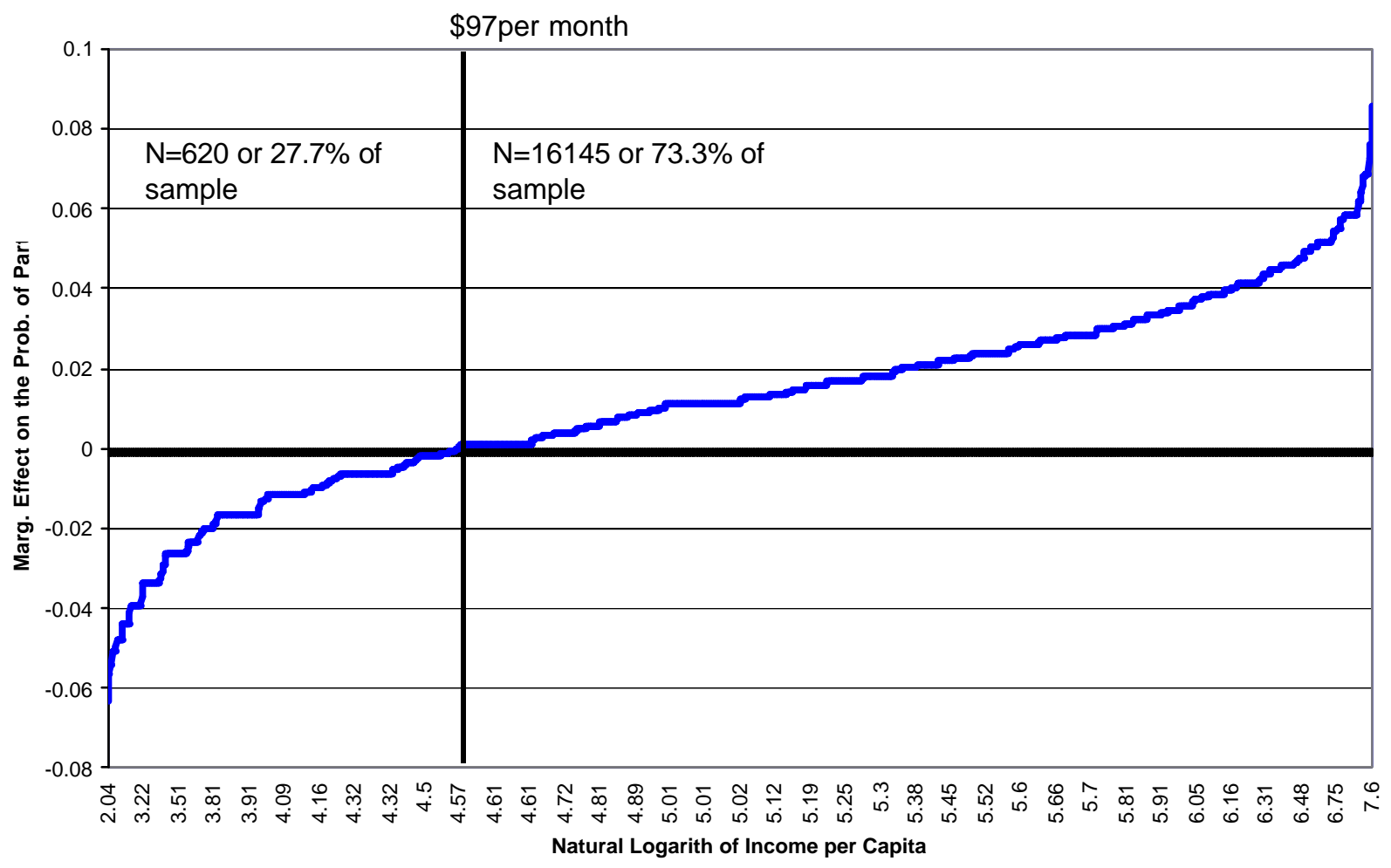


$\underline{\text { Table A1. Summary Statistics }}$

\begin{tabular}{|c|c|c|c|}
\hline Variable & $\begin{array}{c}\text { Percentage of Population } \\
\text { and Means } \\
(\mathrm{N}=2235)\end{array}$ & $\begin{array}{l}\text { Heads of Household } \\
\qquad(\mathrm{N}=1056)\end{array}$ & $\begin{array}{r}\text { Non-Heads } \\
(\mathrm{N}=1179)\end{array}$ \\
\hline Participation in any organization & $19.7 \%$ & $20.7 \%$ & $18.8 \%$ \\
\hline $\begin{array}{l}\text { Interpersonal trust (hypothetical } \\
\text { question) }\end{array}$ & $33.1 \%$ & $36.3 \%$ & $30.2 \%$ \\
\hline Age of respondent (years) & 42.1 & 48.4 & 36.4 \\
\hline $\begin{array}{l}\text { Household income per capita } \\
\text { (dollars per month) }\end{array}$ & 232.1 & 257.7 & 209.2 \\
\hline Unemployed head of household & $6.4 \%$ & $8.9 \%$ & $4.2 \%$ \\
\hline Male respondents & $46.6 \%$ & $71.4 \%$ & $24.3 \%$ \\
\hline $\begin{array}{l}\text { Finished primary education } \\
\text { (respondent) }\end{array}$ & $42.4 \%$ & $42.9 \%$ & $43.0 \%$ \\
\hline $\begin{array}{l}\text { Finished secondary education } \\
\text { (respondent) }\end{array}$ & $23.0 \%$ & $27.8 \%$ & $24.2 \%$ \\
\hline $\begin{array}{l}\text { Finished tertiary education } \\
\text { (respondent) }\end{array}$ & $16.6 \%$ & $12.5 \%$ & $20.3 \%$ \\
\hline University degree (respondent) & $6.5 \%$ & $8.7 \%$ & $4.5 \%$ \\
\hline Homeowners (household) & $78.4 \%$ & $75.2 \%$ & $81.3 \%$ \\
\hline Rural households & $10.7 \%$ & $11.1 \%$ & $10.3 \%$ \\
\hline $\begin{array}{l}\text { Victim in the household } \\
\text { (last year) }\end{array}$ & $20.5 \%$ & $18.3 \%$ & $22.5 \%$ \\
\hline
\end{tabular}

